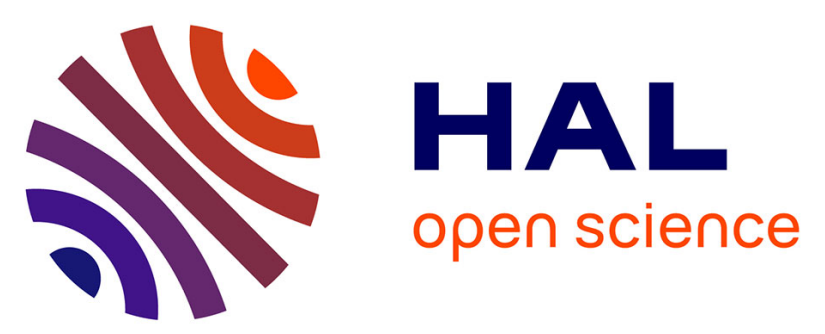

\title{
Curcumin/poly(2-methyl-2-oxazoline-b-tetrahydrofuran- b-2-methyl-2-oxazoline) formulation: An improved penetration and biological effect of curcumin in F508del-CFTR cell lines
}

Cristine Gonçalves, Pierre Gomez, William Même, Bazoly Rasolonjatovo, David Gosset, Steven Nedellec, Philippe Hulin, Cécile Huin, Tony Le Gall, Tristan Montier, et al.

\section{- To cite this version:}

Cristine Gonçalves, Pierre Gomez, William Même, Bazoly Rasolonjatovo, David Gosset, et al.. Curcumin/poly(2-methyl-2-oxazoline-b-tetrahydrofuran-b-2-methyl-2-oxazoline) formulation: An improved penetration and biological effect of curcumin in F508del-CFTR cell lines. European Journal of Pharmaceutics and Biopharmaceutics, 2017, 117, pp.168-181. 10.1016/j.ejpb.2017.04.015 . hal01618274

\author{
HAL Id: hal-01618274 \\ https://hal.science/hal-01618274
}

Submitted on 29 Jun 2018

HAL is a multi-disciplinary open access archive for the deposit and dissemination of scientific research documents, whether they are published or not. The documents may come from teaching and research institutions in France or abroad, or from public or private research centers.
L'archive ouverte pluridisciplinaire HAL, est destinée au dépôt et à la diffusion de documents scientifiques de niveau recherche, publiés ou non, émanant des établissements d'enseignement et de recherche français ou étrangers, des laboratoires publics ou privés. 
Curcumin/poly(2-methyl-2-oxazoline-b-tetrahydrofuran-b-2-methyl-2-oxazoline) formulation: An improved penetration and biological effect of curcumin in F508delCFTR cell lines

Cristine Gonçalves ${ }^{1 \S}$, Jean-Pierre Gomez ${ }^{1 \S}$, William Même ${ }^{1}$, Bazoly Rasolonjatovo ${ }^{2}$, David Gosset $^{1}$, Steven Nedellec ${ }^{5}$, Philippe Hulin ${ }^{5}$, Cécile Huin ${ }^{2}$, Tony Le Gall ${ }^{6}$, Tristan Montier ${ }^{6-7}$, Pierre Lehn ${ }^{6}$, Chantal Pichon ${ }^{1}$, Philippe Guégan ${ }^{3,4}$, Hervé Cheradame $^{2^{*}}$ and Patrick Midoux ${ }^{1 *}$. (1)

${ }^{1}$ Centre de Biophysique Moléculaire, CNRS UPR4301 and Université d'Orléans, France.

${ }^{2}$ Laboratoire Analyse et Modélisation pour la Biologie et l'Environnement, CNRS UMR8587 Université d'Evry Val d'Essonne, Evry, France.

${ }^{3}$ Laboratoire de Chimie des Polymères, Sorbonne Universités, UPMC Univ Paris 06, UMR 8232, IPCM, Chimie des Polymères, F-75005, Paris, France.

${ }^{4}$ CNRS, UMR 8232, IPCM, Chimie des Polymères, F-75005, Paris, France.

${ }^{5}$ Plateforme MicroPICell IFR26 -IRT, Université de Nantes, Nantes, France.

${ }^{6}$ INSERM 1078, équipe « Transfert de gènes et thérapie génique »; Faculté de Médecine et des Sciences de la Santé, Université de Bretagne Occidentale ; Université Bretagne-Loire, 22 avenue Camille Desmoulins, 29238 Brest, France

${ }^{7}$ Laboratoire de génétique moléculaire et d'histocompatibilité, CHRU de Brest, 5 Avenue du Maréchal Foch, 29609 Brest cedex, France

*Corresponding authors: Hervé Cheradame: herve.cheradame@ univ-evry.fr and Patrick

Midoux: patrick.midoux@cnrs-orleans.fr

${ }^{\S}$ Both investigators contributed equally.

Running title: Curcumin/triblock copolymer and F508del-CFTR cells

Keywords: Triblock copolymer; amphiphilic polymer; Curcumin; CFTR; Cystic fibrosis 


\section{Abstract}

Neutral amphiphilic triblock ABA copolymers are of great interest to solubilize hydrophobic drugs. We reported that a triblock ABA copolymer consisting of methyl-2-oxazoline (MeOx) and tetrahydrofuran (THF) $\left(\mathrm{MeOx}_{6}-\mathrm{THF}_{19}-\mathrm{MeOx}_{6}\right)(\mathrm{TBCP} 2)$ can solubilize curcumin (Cur) a very hydrophobic molecule exhibiting multiple therapeutic effects but whose insolubility and low stability in water is a major drawback for clinical applications. Here, we provide evidences by flow cytometry and confocal microscopy that Cur penetration in normal and $\triangle$ F508-CFTR human airway epithelial cell lines is facilitated by TBCP2. When used on $\triangle$ F508-CFTR cell lines, the Cur/TBCP2 formulation promotes the restoration of the expression of the CFTR protein in the plasma membrane. Furthermore, patch-clamp and MQAE fluorescence experiments show that this effect is associated with a correction of a $\mathrm{Cl}^{-}$ selective current at the membrane surface of F508del-CFTR cells. The results show the great potential of the neutral amphiphilic triblock copolymer $\mathrm{MeOx}_{6}-\mathrm{THF}_{19}-\mathrm{MeOx}_{6}$ as carrier for curcumin in a Cystic Fibrosis context. We anticipate that other $\mathrm{MeOx}_{\mathrm{n}}-\mathrm{THF}_{\mathrm{m}}-\mathrm{MeOx}_{\mathrm{n}}$ copolymers could have similar behaviours for other highly insoluble therapeutic drugs or cosmetic active ingredients. 


\section{Introduction}

Many chemotherapeutic drugs or cosmetic active ingredients are very insoluble in water compromising their effectiveness and clinical applications. Delivery of drugs into the cells relies on many constraints such as solubilization, endocytosis or crossing through the membrane lipid bilayer. In this context, more particularly, polymer-based synthetic vectors offer advantages such as relative simplicity of production, safety and versatility. Polyester/ ether ABA triblock copolymers developed as drug delivery system comprise poly(D,Llactide-block-ethylene oxide-block-D,L-lactide) (PLA-PEO-PLA), poly[(D,L-lactide-coglycolide)-block-ethylene oxide-block-(D,L-lactide-co-glycolide)] (PLGA-PEO-PLGA) and $\operatorname{poly}(\varepsilon$-caprolactone-block-ethylene oxide-block- $\varepsilon$-caprolactone (PCL-PEO-PCL) [1]. PPOPEO-PPO copolymers, Pluronic polymers, have been studied quite extensively thanks to the formation of core-shell micelles comprising the polyethylene oxide (PEO) block as the hydrophilic shell of the corona and the polypropylene oxide (PPO) block as the core [2, 3]. Such copolymers have already received large attentions to solubilise hydrophobic molecules for drug delivery $[4,5]$. Certain Pluronic polymers have shown capacity to pass the bloodbrain barrier [2]. They have even demonstrated their ability to increase the biodistribution after oral delivery of molecules poorly soluble in water such as genestein [6]. In a clinical phase I study, doxorubicin bound to a pluronic polymer has demonstrated an increased efficacy compared to free doxorubicin [7]. In the field of immunization with proteins and peptides, neutral amphiphilic copolymers have increased significantly the humoral and cellular responses after intravenous injection [8]. Lutrol has provided efficient gene expression in lung and skeletal muscles upon intratracheal and intramuscular co-injection in mice of plasmid DNA, respectively $[9,10]$. Moreover, DNA vaccination has been obtained with DNA/amphiphilic block copolymer nanospheres [11]. 
Poly(2-oxazolines) based polymers are also interesting biomaterials to solubilize water insoluble molecules [12]. Formulations based on poly(2-oxazoline) polymeric micelles and the effect of parameters related to the structure, formulation, additives and toxicity have been described [4, 13-16]. These reported properties allowed to conclude to the high potential of poly(2-oxazoline) block copolymers, for instance in cancer treatments. Poly(2-methyl-2oxazoline-b-2-butyl-2-oxazoline-b-2-methyl-2-oxazoline $\quad(\mathrm{p}(\mathrm{MeOx}-\mathrm{b}-\mathrm{BuOx}-\mathrm{b}-\mathrm{MeOx})$ has been found to solubilize high quantity of paclitaxel, a very low soluble molecule in aqueous media exhibiting powerful antineoplastic agent, and demonstrated an improved therapeutic effect in xenograft mice tumor models $[17,18]$. A clinical phase I study with a rotigotine polyoxazoline conjugate has been initiated from data obtained in Parkinson's disease [19].

Recently, we have reported the synthesis and characterization of an original family of poly(2-methyl-2-oxazoline-b-tetrahydrofuran-b-2-methyl-2-oxazoline) (MeOx-THF-MeOx) neutral amphiphilic triblock copolymers and showed that some of them solubilized curcumin [20]. Curcumin (diferuloylmethane) (Cur), the natural component of the plant "Curcuma Longa" exhibits multiples therapeutic effects but is very insoluble in water [21]. This is a safe drug even at high doses, but is rapidly metabolized and poorly absorbed by the cells [22]. Curcumin is proposed for treatment of various pulmonary diseases including Asthmas, cancer and Cystic Fibrosis [23]. In order to evidence the interest of curcumin solubilisation by MeOx-THF-MeOx copolymers, we decided to investigate its influence in a Cystic Fibrosis context. Indeed, curcumin has been proposed to treat Cystic fibrosis (CF), the most lethal genetic disease caused by mutations in the gene encoding the Cystic Fibrosis Transmembrane Conductance Regulator (CFTR) $\mathrm{Cl}^{-}$channel resulting in abnormal chloride transport at the plasma membrane of many tissues and organs [24]. $\Delta \mathrm{F} 508$ is the most common mutation of CFTR causing a misfolding of the CFTR protein and its retention in the endoplasmic reticulum (ER) for subsequent proteolytic degradation by the ubiquitin-proteasome pathway 
[25]. Cur can partially compensate the ER retention of the defective CFTR protein, both in vitro in appropriate cell lines and in vivo in F508del-CFTR mice [26, 27]. However, the insolubility and poor stability of Cur in water explain some disappointing results observed in mice treated with Cur [28]. Thus, it appeared for us that curcumin was a good example to test the potential of our amphiphilic copolymers to carry hydrophobic molecules.

Here, we report that the $\mathrm{MeOx}_{6}-\mathrm{THF}_{19}-\mathrm{MeOx}_{6}$ (TBCP2) copolymer facilitates penetration of curcumin in F508del-CFTR cells and preserves the capacity of curcumin to restore a functional CFTR protein.

\section{Material and Methods}

All reagents were purchased from Sigma (St. Quentin Fallavier, France) unless otherwise stated.

\subsection{Polymer synthesis.}

$$
\text { Poly(2-methyl-2-oxazoline) }-b-\operatorname{poly}(\text { tetrahydrofuran })-b-\operatorname{poly}(2-m e t h y l-2-
$$

oxazoline) triblock copolymer (TBCP2). The copolymer was synthesized as described [20]. Briefly, to a $250 \mathrm{~mL}$ reaction flask containing $236 \mathrm{mmol}(17 \mathrm{~g})$ of dry THF, $13.9 \mathrm{mmol}$ (3.91 g) of trifluoromethanesulfonic anhydride $\left(\mathrm{Tf}_{2} \mathrm{O}\right)$ was added at $-9^{\circ} \mathrm{C}$. The reaction mixture was stirred during 15 minutes and the polymerization was quenched by adding $55.6 \mathrm{mmol}(4.7 \mathrm{~g})$ of $\mathrm{MeOx}$ at $-9^{\circ} \mathrm{C}$. Evaporation of residual $\mathrm{THF}$ under reduced pressure yielded to a pTHF prepolymer as a white solid. This solid was dissolved in $40 \mathrm{~mL}$ of dry acetonitrile and the temperature was increased to $80^{\circ} \mathrm{C}$. $\mathrm{MeOx}(88.2 \mathrm{mmol} ; 7.5 \mathrm{~g})$ was added and the solution stirred for 24 hours. The reaction was quenched by $4 \mathrm{~mL}$ of $2 \mathrm{M}$ sodium carbonate solution and stirred for 1 hour at room temperature. The copolymer was dried and the crude yield was $80 \%$. A chloroform/water extraction was then conducted, the organic phase evaporated and dried for 2 days under vacuum. The triblock copolymer had hydroxyl and ester end functions (47\%) as determined by ${ }^{1} \mathrm{H}$ NMR. Molecular weight of TBPC2 determined by ${ }^{1} \mathrm{H}$ NMR was 
2400 g. $\mathrm{mol}^{-1}$ with a p(THF) block containing 19 monomers and 2 p(MeOx) blocks of 6 monomers each.

Rhodamine-labelled TBCP. First the amine terminated copolymer (diamino-TBCP) was synthesized. The $\alpha, \omega$-diamino-poly(2-methyl-2-oxazoline) - block - poly(tetrahydrofuran) block - poly(2-methyl-2-oxazoline), was prepared as above but the polymerization was quenched by addition of a large amount of 1,3-diaminopropane instead of MeOx. Molecular weight of diamino-TBCP was 2200 g.mol ${ }^{-1}$ with a central p(THF) block of 12 monomers and 2 external $\mathrm{p}(\mathrm{MeOx})$ blocks containing 8 monomers each. Despite these variations we have considered that TBCP2 and diamino-TBCP have similar physicochemical behaviours. Rhodamine-labelled TBCP was prepared by reaction of $33 \mathrm{mg}$ diamino-TBCP in $1.5 \mathrm{ml}$ of 0.1 M carbonate bicarbonate buffer, $\mathrm{pH} 9.3$ with $14 \mathrm{mg}(\sim 2.6$ equivalents $)$ of $\mathrm{N}$ hydroxysuccinimide ester activated rhodamine (Invitrogen) dissolved in $0.5 \mathrm{ml}$ dimethyl sulfoxide. The mixture was stirred at room temperature during 24 hours in the dark. A silica gel thin layer chromatography in chloroform/methanol $(1 / 1 \mathrm{vol}: \mathrm{vol})$ revealed the presence of dye bound to the polymer that did not migrate; the fluorescent polymer did not react with ninhydrin. Then, the polymer was purified by precipitation in dichloromethane; the coloured precipitate was washed in ethyl ether and dried under reduced pressure.

\subsection{Curcumin solubilization}

Curcumin was purified by crystallisation in hot ethanol. Curcumin (10 g) was solubilized in $20 \mathrm{~mL}$ pure ethanol under reflux. The hot solution was filtrated, the filtrate was left to cool down and the Cur was collected by filtration (yield $60 \%$ ). A $0.2 \%$ TBCP2 solution was prepared by adding $5 \mathrm{ml} \mathrm{H}_{2} \mathrm{O}$ to $10 \mathrm{mg}$ TBCP2 and vigorous agitation with vortex until complete dissolution. Then $2 \mathrm{mg}$ of Cur were added to the TBCP2 solution, the Cur/TBCP2 (400:2000; $\mu \mathrm{g}: \mu \mathrm{g}$ ) mixture was vortexed and then sonicated for $5 \mathrm{~min}$ at $20^{\circ} \mathrm{C}$ at 
$37 \mathrm{kHz}$. The solution was then clarified by centrifugation $(14,100 \mathrm{x} \mathrm{g}$ for $10 \mathrm{~min})$ to remove any precipitate.

\subsection{Cells and cell culture}

The CFBE41o- human bronchial epithelial (homozygous for the F508del mutation) [29] and $\Sigma$ CFTE29o- human tracheal epithelial (homozygous for the F508del mutation) [30] cell lines carrying the F508del CFTR mutation (so called CF cells) and the 16HBE14onormal human bronchial epithelial cell line [31] (generous gifts from Dieter Gruenert, San Francisco, CA, U.S.A.) were cultured at $37^{\circ} \mathrm{C}$ in a $5 \% \mathrm{CO}_{2}$-humidified incubator in $20 \mathrm{ml}$ MEM with Earle's Salts (PAA Laboratories), 0.4\% Penicillin (40 Units/ml)/Streptomycin (40 $\mu \mathrm{g} / \mathrm{ml}$ ) (PAA Laboratories), 2mM L-Glutamine (PAA Laboratories), supplemented with 10\% heat-inactivated fetal bovine serum (PAA Laboratories). Tissue culture plastic wares $\left(75 \mathrm{~cm}^{2}\right)$ were coated for $20-30$ min at $37^{\circ} \mathrm{C}$ with MEM with Earle's Salts containing fibronectin $(0.01$ $\mathrm{mg} / \mathrm{ml})$, collagen $(0.03 \mathrm{mg} / \mathrm{ml})$ and bovine serum albumin (BSA) $(0.1 \mathrm{mg} / \mathrm{ml})$. The culture medium was changed every 2 days. The absence of mycoplasma in cell cultures was determined by using MycoAlert ${ }^{\circledR}$ Mycoplasma Detection Kit (Lonza, Levallois Perret, France).

\subsection{Curcumin uptake}

Two days prior to the experiments, $1.4 \times 10^{4}$ cells were seeded in $2 \mathrm{~cm}^{2}$ well of a 4well plastic culture plate. For curcumin uptake, cells were incubated at $37^{\circ} \mathrm{C}$ with the curcumin/ TBCP2 solution (stock solution: $1.1 \mathrm{mM}$ Cur in $0.2 \%$ TBCP2) at various concentrations. Then, the cells were washed twice with PBS, harvested by trypsin, centrifuged (800 x $\mathrm{g}$ for $5 \mathrm{~min}$ at $4^{\circ} \mathrm{C}$ ) and suspended in cold PBS. The cell-associated fluorescence intensity was measured with a flow cytometer (FACSort, Becton Dickinson; $\lambda$ ex $=488 \mathrm{~nm}$; $\lambda \mathrm{em}=530 / 30 \mathrm{~nm}$ ) before and after treatment with trypan blue (a final concentration of 0.004 
$\%$ ) in order to quench the extracellular fluorescence of curcumin. The fluorescence intensity was expressed as the mean value of the fluorescence intensity (MFI) of 10,000 cells.

\subsection{Immunofluorescence assays}

Immunofluorescence was carried out with the following antibodies: mouse anti-human CFTR antibodies (Clone M3A7, LifeSpan Biosciences) (dilution 1/50), rabbit anti-calreticulin antibodies (LifeSpan Biosciences) (dilution 1/100), goat anti-calnexin antibodies (C20, Santa Cruz Biotechnology) (dilution 1/100), goat anti-ERGIC-53 antibodies (A-18, Santa Cruz Biotechnology) (dilution 1/100), Alexa Fluor 568 goat anti-mouse antibodies (Invitrogen) (dilution 1/200), Alexa Fluor 568 donkey anti-goat antibodies (Invitrogen) (dilution 1/200), Cy5 sheep anti-mouse antibodies (Jackson Immunoresearch) (dilution 1/100).

\subsection{Confocal microscopy}

The cells $\left(1.4 \times 10^{4}\right)$ were seeded on glass coverslips (14 mm diameter) in $2 \mathrm{~cm}^{2}$ well of a 4-well plastic culture plate. Intracellular locations were performed by immunofluorescence. The cells were washed several times with ice-cold PBS, fixed in cold methanol (90\% in PBS) for 30 min at $-20^{\circ} \mathrm{C}$, washed several times with PBS containing $0.5 \%$ bovine serum albumin (PBS-0.5\%BSA). Coverslips were incubated with primary antibodies in PBS- $1 \%$ BSA for $1 \mathrm{~h}$ at $20^{\circ} \mathrm{C}$, washed with PBS-0.5\%BSA and then incubated for 45 min at $20^{\circ} \mathrm{C}$ with secondary fluorescent antibodies in PBS-1\%BSA. After several washes with PBS, coverslips were mounted in Vectashield (Vector Laboratories, Inc., Burlingame, CA, USA). Confocal laser scanning microscopy (CLSM) was performed using a Zeiss Axiovert 200M microscope coupled with a Zeiss LSM 510 scanning device (Carl Zeiss Co. Ltd., Iena, Germany). The inverted microscope was equipped with a Plan-Apochromat 63X objective $(\mathrm{NA}=1.4)$. The fluorescence was measured at either $560 \mathrm{~nm}$ upon excitation at $543 \mathrm{~nm}$ (Alexa Fluor 568), or $660 \mathrm{~nm}$ upon excitation at $633 \mathrm{~nm}(\mathrm{Cy} 5)$.

\subsection{Electrophysiological measurements}


The cells were cultured on a glass coverslip that was transferred to the experimental chamber of an upright microscope (BX51WI, Olympus Corporation, Tokyo, Japan). Patchclamp experiments were performed at $21-23^{\circ} \mathrm{C}$. Cells were placed in continuously flowing (1$2 \mathrm{ml} / \mathrm{min}$ ) bath solution containing $(\mathrm{mM}): 150 \mathrm{NaCl} ; 6 \mathrm{CsCl} ; 1 \mathrm{CaCl}_{2} ; 1 \mathrm{MgCl}_{2} ; 10 \mathrm{D}-$ glucose; 10 HEPES (adjusted to $\mathrm{pH} 7.4$ with Tris) and identified at 60x magnification with a CCD camera (XC-ST70CE, Sony). Somatic whole-cell recordings were performed as previously described [32]. Briefly, low resistance (4-6 M 2 ) patch-pipettes pulled on a vertical puller (PB-7, Narishige, Tokyo, Japan) from borosilicate capillaries (Clark Electromedical Instruments, Edenbridge, UK) were filled with internal solution containing (mM): $100 \mathrm{~L}-$ aspartic acid; $94 \mathrm{CsOH} ; 26 \mathrm{CsCl} ; 14 \mathrm{NaCl} ; 1 \mathrm{MgCl}_{2} ; 3 \mathrm{MgATP} ; 1$ EGTA; 10 HEPES (adjusted to $\mathrm{pH} 7.3$ with Tris). Signals were amplified using the MultiClamp 700B amplifier (Axon Instruments, Foster City, CA). Series resistance was monitored continuously and was typically compensated by $60-70 \%$ in whole-cell configuration. Voltage-clamp recordings were filtered at $4 \mathrm{kHz}$, sampled at $10 \mathrm{kHz}$ using a data acquisition board (Digidata 1322A, Axon Instruments) operated by Pclamp10 software (Axon Instruments). Off-line analysis was performed using Clampfit10 (Axon Instruments) and Origin8 (Origin Lab Corporation, Northampton, MA). 16HBE14o- and $\Sigma$ CFTE29o- cells were cultured under control conditions or in the presence of $\mathrm{Cur} / \mathrm{TBCP} 2$ treatment. Currents were elicited by voltage steps applied from $-110 \mathrm{mV}$ to $+70 \mathrm{mV}$ (10 $\mathrm{mV}$ increments, $400 \mathrm{~ms}$ duration) from a holding potential (HP) of $-40 \mathrm{mV}$. Steady-state current amplitude was measured at the end of the pulse and normalized to the cell membrane capacitance $(17.6 \pm 1.5 \mathrm{pF}, \mathrm{n}=19$ on $16 \mathrm{HBE} 14 \mathrm{o}-$ cells; 22.1 $\pm 1.2 \mathrm{pF}, \mathrm{n}=28$ on $\Sigma$ CFTE29o- cells).

\subsection{MQAE fluorescence assay}

The $\mathrm{Cl}^{-}$channel activity of CFTR was assessed on 16HBE14o- and CFBE41o- cells using the halide-sensitive fluorescent probe MQAE [33]. Cells were loaded with MQAE 
intracellular dye by incubation for $8 \mathrm{~min}$ at $37^{\circ} \mathrm{C}$ in a hypotonic medium (mM) (110 NaI, 1.92 $\mathrm{K}_{2} \mathrm{HPO}_{4}, 0.64 \mathrm{KH}_{2} \mathrm{PO}_{4}, 8$ HEPES , $0.8 \mathrm{CaSO}_{4}, 8$ D-Glucose, $\mathrm{pH}$ 7.4) containing $10 \mathrm{mM}$ MQAE. Coverslips were mounted on the stage of an inverted microscope (LEICA DMI 6000B) equipped for fluorescence, and cell fluorescence was excited at $380 \mathrm{~nm}$. The emitted fluorescence was detected at $470 \mathrm{~nm}$ by a CCD camera coolsnap HQ2 (Roper). Cells were maintained at $37^{\circ} \mathrm{C}$ and continuously perfused with an extracellular bath solution containing (mM): $138 \mathrm{NaI}, 2.4 \mathrm{~K}_{2} \mathrm{HPO}_{4}, 0.8 \mathrm{KH}_{2} \mathrm{PO}_{4}, 10 \mathrm{HEPES}, 1 \mathrm{CaSO}_{4}, 10$ D-Glucose, pH 7.4. A superfusion system (Biosciences Tools) allowed rapid change of different extracellular experimental media. Cells were sequentially perfused with $138 \mathrm{mM} \mathrm{I}^{-}$buffer solution, 138 $\mathrm{mM} \mathrm{NO}_{3}{ }^{-}$buffer solution, $138 \mathrm{mM} \mathrm{NO}_{3}{ }^{-}$buffer solution with $0.5 \mathrm{mM}$ 8-(4-chlorophenyl)thiocyclic AMP (8-CPT-cAMP) and again with $138 \mathrm{mM} \mathrm{\textrm {I } ^ { - }}$ buffer solutions. Single cell fluorescence intensity was plotted against time at an acquisition rate of 1 image per 15 seconds. Fluorescence intensity was normalized to the initial fluorescence level measured in the presence of $I^{-}$.

\section{Results}

\subsection{Curcumin solubilisation and penetration into CF and normal airway epithelial cell lines}

The $\mathrm{MeOx}_{6}-\mathrm{THF}_{19}-\mathrm{MeOx}_{6} \mathrm{ABA}$ copolymer (TBCP2) of $2400 \mathrm{~g} \cdot \mathrm{mol}^{-1}$ was composed of 12 poly(2-methyl-2-oxazoline) (MeOx) hydrophilic blocks A and 19 polytetrahydrofuran (THF) hydrophobic blocks B (Fig. 1A). The chemical shifts of the pTHF blocks were at 1.61 ppm and $3.40 \mathrm{ppm}$, those of the pMeOx ones at $2.13 \mathrm{ppm}\left(\mathrm{CH}_{3}\right.$ groups $)$ and $3.42 \mathrm{ppm}$ and those of the telechelic $\mathrm{CH}_{2}$ groups adjacent to the end hydroxyl functions at $3.78 \mathrm{ppm}$ (Fig. 1C). The surprising high dispersity $(\nexists=4.5)$ was attributed to the low molar mass of the pTHF block associated to the reversible cationic ring opening polymerization of THF. The standard conditions for $\mathrm{MeOx}$ polymerization allowed expecting a much better control of these blocks synthesis as previously reported [34]. The amphiphilic feature in aqueous 
solution and self-assembling to form micelles of TBCP2 were determined by different techniques including Nile Red fluorescence spectroscopy (F), isothermal titration calorimetry (ITC), dynamic light scattering (DLS) [20]. The critical micellar concentration was $3.2 \times 10^{-3}$ mol.L $\mathrm{L}^{-1}, 6.5 \times 10^{-4}$ mol. $\mathrm{L}^{-1}, 4.2 \times 10^{-4}$ mol. $\mathrm{L}^{-1}$ to $1 \times 10^{-3}$ mol. $\mathrm{L}^{-1}$ as determined by F, ITC and DLS, respectively. In a $0.2 \%$ solution in water, TBCP2 formed micelles with a hydrodynamic diameter of $16 \pm 1.4 \mathrm{~nm}$ as determined by DLS (Fig. 1D). The solubilisation of $2 \mathrm{mg}$ Cur (400 $\mu \mathrm{g} / \mathrm{ml} ; 1.1 \mathrm{mM}$ ) was achieved by mixing, vortexing and then sonicating $2 \mathrm{mg}$ Cur in $5 \mathrm{ml}$ of $0.2 \%$ TBCP2 in water (Fig. 1B). In contrast, Cur was completely insoluble in water in the absence of TBCP2 (Fig. 1B). The resulting Cur/TBCP2 formulation (17 wt.\%) formed nanoparticles of $255 \pm 30 \mathrm{~nm}$ (Fig. 1D).

We then tested whether the Cur/TBCP2 formulation allowed for Cur uptake by the cells. For this purpose, two CF (इCFTE29o- and CFBE41o-) and one normal (16HBE14o-) human airway epithelial cell lines were incubated in complete culture medium at $37^{\circ} \mathrm{C}$ in the presence of Cur solubilized in TBCP2 or TBCP2 without Cur. After $2 \mathrm{~h}$ incubation, Cur location was analysed by fluorescence microscopy thanks to Cur fluorescence at $520 \mathrm{~nm}$ upon excitation at $488 \mathrm{~nm}$. As shown in Figure 2, the fluorescence was in the cytoplasm with Cur/TBCP2 showing penetration of Cur in these cell lines. In contrast, no fluorescence was detected in the cells incubated with TBCP2 in the absence of Cur or the supernatant of Cur in PBS (Fig. 2). The Cur fluorescence intensity associated with the cells was measured by flow cytometry after $2 \mathrm{~h}$ incubation with various dilution of the Cur/TBCP2 formulation. As shown in Figure 3, the mean fluorescence intensity (MFI) increased with the Cur concentration. Those MFI corresponded to the fluorescence of Cur. Indeed, MFI of the three cell lines incubated with TBCP2 at the concentration used to solubilize $220 \mu \mathrm{M}$ Cur were the same as MFI (2.5 A.U) measured for those cells incubated in the medium without any polymer and Cur. MFI were reduced after treatment with trypan blue which quenched the extracellular 
curcumin fluorescence and thus the residual MFI were indicative of Cur internalization. The amounts of Cur associated with the three cell lines and that taken up by the three cell lines were comparable. About $\sim 55 \%$ of Cur associated with the cells was inside the cells. For information, MFI upon trypan blue treatment of $\Sigma$ CFTE29o-, 16HBE14o- and CFBE41ocells incubated with $27.5 \mu \mathrm{M}$ Cur solubilized in DMSO were 45, 13 and 18, respectively, indicating that the penetration of Cur was larger than Cur solubilized in TBCP2 micelles. We evaluated by confocal microscopy the uptake of the copolymer by incubating those cell lines for $4 \mathrm{~h}$ at $37^{\circ} \mathrm{C}$ with a Cur/Rho-TBCP formulation (Fig. 4). The images showed that the copolymer did not enter deeply into the cytoplasm of $\Sigma$ CFTE29o- cells while curcumin enters the cells. It was mostly remained close to the cell surface either at and/or under the cell surface while a few amount of polymer was inside the cells. Regarding the bronchial epithelial cells (CFBE41o-and 16HBE14o- cells), the presence of yellow spots in the cytoplasm was indicative of higher TBCP internalization than in the tracheal epithelial cells ( CFTE29o- cells). Next, the evaluation of the effect of curcumin on CFTR in F508del-CFTR cells was studied. The CFTR intracellular location was performed by immunofluorescence and confocal microscopy analysis, and its functionality (assessed via chloride current measurements) by patch-clamp experiments and MQAE fluorescence assay.

\subsection{Effect of Cur/TBCP2 on CFTR intracellular location}

Before testing the Cur/TBCP2 effect, the intracellular distribution of CFTR was examined in F508del-CFTR and normal cells by immunofluorescence and confocal microscopy. The cells were labelled with anti-CFTR antibodies and also with antibodies directed against calreticulin or calnexin which are two quality-control chaperones that bind to misfolded proteins such as the muted CFTR and prevent them from being exported from the ER to the Golgi apparatus for complete glycosylation. The cells were also stained with antibodies directed against ergic-53 because previous observations suggested that F508del- 
CFTR was also present in the Endoplasmic reticulum intermediate compartment (ERGIC) [35]. Confocal microscopy images showed that in normal (16HBE14o-) cells, CFTR was located at the periphery of the cells or at the plasma membrane (blue spots) and very few colocations (white spots) were observed with calreticulin or calnexin (Fig. 5). CFTR was logically detected also in ergic-53 en route for its glycosylation in the Golgi. In $\Sigma$ CFTE29ocells, the F508del-CFTR was mostly concentrated in the perinuclear region and strongly colocalized with antibodies directed against calnexin and ergic-53 in line with the retention of the mutated protein in the ER/ERGIC compartments of cells expressing the F508del-CFTR (Fig. 5). The retention effect in ERGIC looked stronger in $\Sigma$ CFTE29o- cells with the presence of many white spots and no blue ones than in CFBE41o- cells. The F508del-CFTR distribution in CFBE41o- looked like that the CFTR in 16HBE14o- cells suggesting localization in the plasma membrane. However, it was reported that the F508del-CFTR was distributed in the cytoplasm of CFBE41o- cells [36]. The CFBE41o- cells are bronchial epithelial cells while the $\Sigma$ CFTE29o- cells are from tracheal epithelial cells. The intracellular distribution of the F508del-CFTR could vary with the nature of the pulmonary epithelial tissues [37]. Of note, the F508del-CFTR location in the calreticulin compartment looked weak in the CF cell lines.

When $\Sigma$ CFTE29o- cells were incubated overnight with $220 \mu \mathrm{M}$ Cur solubilized with TBCP2, CFTR was not located in the ER/ERGIC compartment near the nucleus as in absence of Cur but its distribution was similar as in the normal 16HBE14o- cells indicating CFTR redistribution in the presence of Cur (Fig. 6). This redistribution after incubation of CFBE41o- cells with the Cur/TBCP2 solution was not as demonstrative as in ECFTE29ocells (Fig. 6). This could be explained by the lower retention of F508del-CFTR in ERGIC of CFBE41o- cells comparatively to LCFTE29o- cells (Fig 5). As expected, no modification was observed in normal 16HBE14o- cells in which CFTR was mostly at the plasma membrane 
(Fig. 6). The images reconstitution of several z steps as well as sections of the $\mathrm{z}$-step gallery passing through the middle of a representative $\Sigma$ CFTE29o-cell showed clearly that F508delCFTR was concentrated at the nucleus periphery in the absence of Cur while it was distributed throughout the cell and at the plasma membrane in the presence of Cur (Fig. 7). These results evidenced that incubation of F508del-CFTR cells with the Cur/TBCP2 solution promoted the relocation of the CFTR at the plasma membrane.

\subsection{CFTR current specific activation by Cur/TBCP2 treatment}

Whole-cell patch-clamp experiments were carried out to determine the activation of CFTR chloride current after incubation of CF cells with Cur/TBCP2 solution. First, wholecell patch-clamp experiments were performed in normal (16HBE14o-) and CF (इCFTE29o-) cells in the absence of Cur/TBCP2. The measurement of the associated averaged steady-state current-voltage (I/V) relationships revealed the presence of a high chloride induced current $(15.3 \pm 2.8 \mathrm{pA} / \mathrm{pF})$ in normal cells (Fig. 8Aa and 8B black squares) whereas in CF cells (Fig. $8 \mathrm{Ab}$ and $8 \mathrm{~B}$, black circles) a weak chloride current $(3.1 \pm 0.5 \mathrm{pA} / \mathrm{pF})$ was measured at a potential of $+60 \mathrm{mV}$. In the presence of $10 \mu \mathrm{M}$ CFTRinh-172 - a specific CFTR inhibitor [38] the chloride current was strongly inhibited in 16HBE14o- cells (Fig. 8B, white squares). In contrast the effect was limited in CF cells (Fig. 8B, white circles). The CFTRinh-172 current sensitivity in $16 \mathrm{HBE} 14 \mathrm{o}-$ cells $(9.3 \pm 2.9 \mathrm{pA} / \mathrm{pF}$ at a potential of $+60 \mathrm{mV})$ was 7 -fold higher than in $\Sigma$ CFTE29o- cells $(1.3 \pm 0.3 \mathrm{pA} / \mathrm{pF})$. The chloride current measured in both cell lines was also inhibited by $20 \mu \mathrm{M}$ GlyH-101 - another specific CFTR inhibitor - [39] (data not shown). All together these data demonstrated that chloride currents measured on these different cell lines corresponded to a CFTR chloride current and were in line with those as previously described for these two cell lines [40, 41].

Figure 9 presents characteristic whole-cell currents in Cur/TBCP2-treated $\Sigma$ CFTE29ocells in the absence and the presence of $10 \mu \mathrm{M}$ CFTRinh-172. CFTR currents were 
equivalently blocked on this cell lines by CFTRinh-172 and GlyH-101, the experiments were then conducted with CFTRinh-172 only. Compared to untreated cells, the incubation with Cur/TBCP2 induced a current enhancement that was strongly inhibited in the presence of CFTRinh-172 (Fig. 9A). The CFTRinh-172 current sensitivity was calculated as the difference between currents measured prior and after CFTR-inh 172 exposure, in the same way as done for Fig. 9B. CFTRinh-172 current sensitivity plotted as current-voltage (I-V) relationships revealed that incubation of $\Sigma$ CFTE29o- cells with Cur/TBCP2 $(120 \mu \mathrm{M})$ induced a statistically significant increase in CFTRinh-172 current sensitivity at all membrane potential tested (Fig. 9B). Cur/TBCP2 induced a linear conductance typical of a $\mathrm{Cl}^{-}$selective current. At $+30 \mathrm{mV}$, the current density reached $4.5 \pm 1 \mathrm{pA} / \mathrm{pF}$ with Cur/TBCP2 versus $1 \pm$ $0.6 \mathrm{pA} / \mathrm{pF}$ under basal conditions. The observed zero current potential was $-39.3 \pm 0.1 \mathrm{mV}$ $(n=19)$ a value that closely matched the chloride reversal potential $(-33.8 \mathrm{mV})$ predicted by the Nernst equation with an internal $\left[\mathrm{Cl}^{-}\right]$of $42 \mathrm{mM}$ and external $\left[\mathrm{Cl}^{-}\right]$of $160 \mathrm{mM}$, suggesting channel selectivity for $\mathrm{Cl}^{-}$. All together, these results strongly supported that Cur/TBCP2 induced the expression of a $\mathrm{Cl}^{-}$selective current at the membrane surface of $\Sigma$ CFTE29o- cells typical of new functional CFTR channels.

\subsection{CFTR Cl activity assessed by MQAE fluorescence assay}

The functional measurement of the CTFR expression in the different airway epithelial cells was also assessed by using the chloride fluorescent probe MQAE [33]. The fluorescence of MQAE is quenched in the presence of chloride or iodide ions in CF cells but its fluorescence is restored in response to $\mathrm{I}^{-} / \mathrm{NO}_{3}{ }^{-}$substitution and cAMP stimulation after CFTR restoration. Figure 10 presents MQAE fluorescence measurements using $\mathrm{I}^{-}, \mathrm{NO}_{3}{ }^{-}, \mathrm{NO}_{3}{ }^{-}+$ cAMP (8-CPT-cAMP) solution substitution protocol in normal 16HBE14o-, untreated and Cur/TBCP2-treated CFBE41o- cell monolayers. In contrast to 16HBE14o- cells (Fig. 10A), 
MQAE fluorescence was not changed in untreated CFBE41o- cells upon $\mathrm{I}^{-}$substitution by $\mathrm{NO}_{3}{ }^{-}$or was slightly induced by cAMP $+\mathrm{NO}_{3}{ }^{-}$(amplitude $10.96 \pm 2.6$ ) (Fig. 10B).

The incubation of the CFBE41o- cell monolayer with Cur/TBCP2 (165 $\mu \mathrm{M})$ drastically restored the MQAE fluorescence response to $\mathrm{I}^{-} / \mathrm{NO}_{3}{ }^{-}$substitution (amplitude 24.4 \pm 4.4 ) and particularly in response to cAMP stimulation (amplitude $39.55 \pm 6.6$ ) (Fig. 10C). The fluorescence amplitude variation of the fluorescence intensity used as an index of CFTR activity demonstrated a specific restoration of the CFTR activity in CF cells treated with Cur/TBCP2 close to that observed in normal cells (Fig. 10D). Of note, MQAE fluorescence testing was not performed with $\Sigma$ CFTE29o- cells because the functional restoration of F508del-CFTR was convincing by Patch-clamp measurements (Fig 9). In contrast it was less demonstrative with CFBE41o- cells.

\section{Discussion}

Several strategies have been explored to improve solubility and stability of Cur in water. For instance, Cur was conjugated to sugars [42, 43], amino acids [44] and polyethylene glycol [45, 46]. Formulations with carriers were also explored [47, 48]. For instance, Cur solubility and activity were improved upon inclusion in cyclodextrin [49] or encapsulation in liposomes [50-52], chitosan/poly(butyl cyanoacrylate) nanoparticles [53, 54], PLGA nanoparticles [55] or methoxy poly(ethylene glycol)-block-polycaprolactone diblock copolymers micelles [56]. Cur effect was enhanced in CF mice upon oral administration of Cur encapsulated in biodegradable nanoparticles made of an oil-in-water emulsion mixture of poly (lactic-co-glycolic acid) (PLGA) and poly(vinyl alcohol) [57]. ABA copolymers comprising poly(ethylene oxide) (PEO) block as the hydrophilic moiety and poly(propylene oxide) (PPO) block as hydrophobic moiety forming core-shell micelles were also used. However, PEO polymers due either to the polymer itself or a side product formed during its synthesis can generate various unfavourable effects [58]. Polyoxazoline was proposed as an 
alternative to PEO $[15,59]$ and a family of poly(2-methyl-2-oxazoline-b-tetrahydrofuran-b-2methyl-2-oxazoline) (MeOx-THF-MeOx) neutral amphiphilic triblock copolymers (TBCP) have been synthesized [20]. Our Cur/TBCP2 formulation (17 wt.\%) was obtained by solubilisation of Cur $(0.5 \mathrm{mg})$ in a water solution of micelles of TBCP2 copolymer $(2 \mathrm{mg} / \mathrm{ml}$; 2400 g.mol ${ }^{-1}$ ). Comparatively, the preparation of $1 \mathrm{mg} / \mathrm{ml}$ curcumin with $10 \mathrm{mg} / \mathrm{ml}$ of 1,2dimyristoyl-sn-glycero-3-phosphocholine and 1,2-dimyristoyl-sn-glycero-3-phospho-rac-(1glycerol) liposomes was described [52]; the preparation of $14 \% \mathrm{wt} \%$ and $7.6 \% \mathrm{wt} \%$ curcumin formulations were reported with methoxy poly(ethylene glycol)-blockpolycaprolactone diblock copolymers micelles [56] and poly (lactic-co-glycolic acid) (PLGA) and poly(vinyl alcohol) nanoparticles [57], respectively. With another highly hydrophobic drug, the preparation of a 45 wt.\% Paclitaxel formulation was successfully achieved with the $\mathrm{MeOx}_{37}-\mathrm{b}-\mathrm{BuOx}_{23}-\mathrm{b}-\mathrm{MeOx}_{37}$, a triblock copolymer of 10000 g.mol ${ }^{-1}$ [15]. The resulting Cur/TBCP2 solution formed nanoparticles of $\sim 250 \mathrm{~nm}$ while a $0.2 \%$ TBCP2 in water formed micelles of $\sim 16 \mathrm{~nm}$. The large size of TBCP2/Cur nanoparticles could result from the coalescence of TBCP2 micelles around Cur aggregates. Here, we show that TBCP2 allowed Cur internalization by human airway epithelial cell lines. Yet, the penetration of Cur was lower than when Cur was solubilized in DMSO which allows Cur diffusion through the plasma membrane. The uptake mechanism of Cur in TBCP2 micelles is not yet determined but it could process via a transient destabilization of the plasma membrane by TBCP2. Indeed, Rho-TBCP does not enter deeply into the cytoplasm of the tracheal epithelial cells while Cur enters the cells. This suggests that once bound to the plasma membrane, the copolymer would destabilize the lipid bilayer inducing Cur diffusion through the plasma membrane. The copolymer that is more internalized in the bronchial epithelial cells would in addition induce the formation of transient pores in endocytic vesicles allowing Cur diffusion in the cytoplasm. This latter hypothesis is supported by data showing that a neutral 
amphiphilic diblock copolymer - a poly(ethylene oxide-b-4-vinylpyridine) - was able to form transient pores in a lipid artificial membrane allowing the passage of a plasmid DNA of $\sim 5$ kbp across the model membrane [60].

Here, we have evaluated the biofunctionality of curcumin after solubilisation by TBCP2. For this purpose, we have tested whether the Cur/TBCP2 formulation could restore the expression of a functional CFTR protein at the surface of F508del-CFTR cells. Indeed, F508del-CFTR is not expressed at the plasma membrane because it is retained in the ER/ERGIC compartment by the quality control system involving calreticulin and/or calnexin [61]. Our immunofluorescence analyses performed on two F508del-CFTR cell lines verified that F508del-CFTR colocates with calnexin and calreticulin. They confirmed also that F508del-CFTR colocates with ERGIC-53, a protein specific of the ERGIC compartment as previously reported [35]. p58/ERGIC-53 is a calcium-dependent lectin recognizing mannose that cycles between the ER and the Golgi apparatus and functions as a cargo receptor for a subset of soluble glycoproteins exported from the ER. The lectin domains of ERGIC-53 and calnexin are structurally similar. F508del-CFTR is not exported to the Golgi for maturation but is driven to the cytosolic ubiquitin-proteasome machinery for degradation. It has been shown that ERGIC compartment accumulates proteins on the way for degradation as the precursor of human asialoglycoprotein receptor $\mathrm{H} 2 \mathrm{a}$ and free heavy chains of murine class I major histocompatibility complex (MHC) [62]. Significant amounts of various ER resident proteins have been detected in ERGIC indicating that a leak of calnexin from ER into ERGIC might occur [63]. Thus, calnexin could be transiently present in ERGIC which could be a site for the concentration and retrotranslocation of proteins that are transported to the cytosol. That explains colocations between F508del-CFTR and p58/ERGIC-53 observed in the F508del-CFTR cell lines. 

protein in appropriate cell lines and in F508del-CFTR mice [26, 27]. We demonstrate that incubation of F508del-CFTR cell lines with Cur/TBCP2 induces the relocation of the mutated penetration of Cur upon solubilization in the TBCP2 solution. The functionality of CFTR chloride channels in the apical membrane of CF cells after incubation with Cur/TBCP2 is clearly revealed by whole-cell patch-clamp experiments and MQAE fluorescence assay. In the former, the specificity of the activation of CFTR currents is provided by the use of CFTRinh-172 or GlyH-101, two specific CFTR inhibitors that both induce strong inhibition of restored currents in CF cells treated with Cur/TBCP2. CFTRinh-172 is a well-known and 450 widely used specific inhibitor of CFTR channels, without affecting other chloride 451 conductance such as the $\mathrm{Ca}^{+}$-dependent $\mathrm{Cl}^{-}$conductance $(\mathrm{CaCC})$ or the volume-sensitive outwardly rectifying $\mathrm{Cl}^{-}$conductance (VSORC). GlyH-101 appears less specific as it inhibits both VSORC and $\mathrm{CaCC}$ at concentrations close to those used to inhibit CFTR conductance [64]. Therefore, our calculated CFTRinh-172 current sensitivity was due to CFTR current. The fluorescence assay with the chloride sensitive fluorescent probe MQAE which is 456 quenched in the presence chloride or iodide ions is drastically restored in CF cells after Cur/TBCP2 treatment in response to $\mathrm{I}^{-} / \mathrm{NO}_{3}^{-}$substitution and cAMP stimulation. All together, these results provide strong evidences that the CFTR relocation leads to a functional chloride channel.

The exact mechanism by which Cur allows the F508del-CFTR relocation is not fully 461 understood. Cur is an inhibitor of the sarcoplasmic/endoplasmic reticulum $\mathrm{Ca}^{2+}$-ATPase 462 (SERCA) involved in the translocation of calcium from the cytosol to the sarcoplasmic reticulum lumen [65-67]. The lectin-like recognition of calreticulin, calnexin and ERGIC-53 that binds to the terminal glucose of the $\mathrm{N}$-oligosaccharide structure of misfolded 
glycoproteins is calcium-dependent. SERCA inhibition by Cur via the modulation of sarcoplasmic reticulum calcium content could prevent retention of F508del-CFTR in the ER/ERGIC favouring its delivery in the Golgi apparatus for maturation and exocytosis to the plasma membrane. It has also been reported that the trafficking of CFTR to the plasma membrane involves the keratin 8/keratin 18 network of intermediate filaments [68, 69]. An important remodelling in the keratin 18 network has been indeed observed in Cur-treated cells with an increase in the phosphorylation of K18 Ser52 in a calcium-independent manner [70]. This reorganization reduces the intracellular trafficking of organelles mediated by the intermediate filaments and the turnover of some membrane proteins as CFTR. Inhibitions by Cur of the ER retention of F508del-CFTR and its turnover from the plasma membrane could contribute to the restoration of a functional CFTR in the plasma membrane. Curcumin was proposed to treat Cystic Fibrosis but its multiple therapeutic effects as well as the absence of fully understanding mechanism (s) of action delay its FDA agreement. For this raison, curcumin is often named as pan-assay interference (PAIN) compound, classes of compounds that can interfere with bioassays via a number of different mechanisms [71].

\section{Conclusion}

We demonstrated the great potential of the $\mathrm{MeOx}_{6}-\mathrm{THF}_{19}-\mathrm{MeOx}_{6}$ copolymer to solubilize a very insoluble molecule such as curcumin. In a cystic fibrosis context, we showed that curcumin better penetrated normal and F508del-CFTR human airway epithelial cells and promoted a functional expression of the mutated CFTR protein in the plasma membrane of the CF cells. More generally, $\mathrm{MeOx}_{\mathrm{n}}-\mathrm{THF}_{\mathrm{m}}-\mathrm{MeOx}_{\mathrm{n}}$ copolymers could help solubilisation of other water insoluble drugs or cosmetic ingredients contributing to their better applications.

\section{Acknowledgments:}


489 We warmly thank Dr. Dieter Gruenert who passed away on April 9, 2016 for giving us his 490 cell lines we used in our various studies since several years. We thank the "Cytometry and

491

492

493

494

495

496

497

498

499

500

501

502

503

504

505

506

507

508

509

510

511

512

Cell Imaging” P@CYFIC platform” at CBM Orléans. We certify that there is no conflict of interest, no competing of interest and no disclosure.

\section{References}

[1] T. Kissel, Y. Li, F. Unger, ABA-triblock copolymers from biodegradable polyester Ablocks and hydrophilic poly(ethylene oxide) B-blocks as a candidate for in situ forming hydrogel delivery systems for proteins, Advanced drug delivery reviews, 54 (2002) 99-134.

[2] A.V. Kabanov, E.V. Batrakova, D.W. Miller, Pluronic block copolymers as modulators of drug efflux transporter activity in the blood-brain barrier, Adv. Drug Deliv. Rev., 55 (2003) $151-164$.

[3] A.V. Kabanov, J. Zhu, V. Alakhov, Pluronic block copolymers for gene delivery., Adv. Genet., 53 (2005) 231-261.

[4] M.L. Adams, A. Lavasanifar, G.S. Kwon, Amphiphilic block copolymers for drug delivery, J Pharm Sci, 92 (2003) 1343-1355.

[5] G.S. Kwon, Polymeric micelles for delivery of poorly water-soluble compounds, Crit Rev Ther Drug Carrier Syst, 20 (2003) 357-403.

[6] S.H. Kwon, S.Y. Kim, K.W. Ha, M.J. Kang, J.S. Huh, T.J. Im, Y.M. Kim, Y.M. Park, K.H. Kang, S. Lee, J.Y. Chang, J. Lee, Y.W. Choi, Pharmaceutical evaluation of genisteinloaded pluronic micelles for oral delivery., Arch. Pharm. Res., 30 (2007) 1138-1143.

[7] S. Danson, D. Ferry, V. Alakhov, J. Margison, D. Kerr, D. Jowle, M. Brampton, G. Halbert, M. Ranson, Phase I dose escalation and pharmacokinetic study of pluronic polymerbound doxorubicin (SP1049C) in patients with advanced cancer, Br J Cancer, 90 (2004) 20852091. 
513 [8] M.J. Newman, J.K. Actor, M. Balusubramanian, C. Jagannath, Use of non ionic block copolymers in vaccines and therapeutics., Crit. Rev. Ther. Drug Carrier Syst., 15 (1998) 89142.

[9] L. Desigaux, C. Gourden, M. Bello-Roufai, P. Richard, N. Oudrhiri, P. Lehn, D. Escande, H. Pollard, B. Pitard, Nonionic amphiphilic block copolymers promote gene transfer to the lung, Hum Gene Ther, 16 (2005) 821-829.

[10] P. Richard, F. Bossard, L. Desigaux, C. Lanctin, M. Bello-Roufai, B. Pitard, Amphiphilic block copolymers promote gene delivery in vivo to pathological skeletal muscles, Hum Gene Ther, 16 (2005) 1318-1324.

[11] D. McIlroy, B. Barteau, J. Cany, P. Richard, C. Gourden, S. Conchon, B. Pitard, DNA/amphiphilic block copolymer nanospheres promote low-dose DNA vaccination, Mol Ther, 17 (2009) 1473-1481.

[12] N. Adams, U.S. Schubert, Poly(2-oxazolines) in biological and biomedical application contexts, Advanced drug delivery reviews, 59 (2007) 1504-1520.

[13] Y. Seo, A. Schulz, Y. Han, Z. He, H. Bludau, X. Wan, J. Tong, T.K. Bronich, M. Sokolski, R. Luxenhofer, R. Jordan, A.V. Kabanov, Poly(2-oxazoline) block copolymer based formulations of taxanes: effect of copolymer and drug structure, concentration, and environmental factors. , Polym. Adv. Technol. , 26 (2015) 837-850.

[14] R. Luxenhofer, G. Sahay, A. Schulz, D. Alakhova, T.K. Bronich, R. Jordan, A.V. Kabanov, Structure-property relationship in cytotoxicity and cell uptake of poly(2-oxazoline) amphiphiles, Journal of controlled release : official journal of the Controlled Release Society, 153 (2011) 73-82.

[15] R. Luxenhofer, A. Schulz, C. Roques, S. Li, T.K. Bronich, E.V. Batrakova, R. Jordan, A.V. Kabanov, Doubly amphiphilic poly(2-oxazoline)s as high-capacity delivery systems for hydrophobic drugs, Biomaterials, 31 (2010) 4972-4979. 
[16] A. Schulz, S. Jaksch, R. Schubel, E. Wegener, Z. Di, Y. Han, A. Meister, J. Kressler, A.V. Kabanov, R. Luxenhofer, C.M. Papadakis, R. Jordan, Drug-induced morphology switch in drug delivery systems based on poly(2-oxazoline)s, ACS nano, 8 (2014) 2686-2696.

[17] Z. He, X. Wan, A. Schulz, H. Bludau, M.A. Dobrovolskaia, S.T. Stern, S.A. Montgomery, H. Yuan, Z. Li, D. Alakhova, M. Sokolsky, D.B. Darr, C.M. Perou, R. Jordan, R. Luxenhofer, A.V. Kabanov, A high capacity polymeric micelle of paclitaxel: Implication of high dose drug therapy to safety and in vivo anti-cancer activity, Biomaterials, 101 (2016) 296-309.

[18] S. Jaksch, A. Schulz, Z. Di, R. Luxenhofer, R. Jordan, C.M. Papadakis, Amphiphilic Triblock Copolymers from Poly(2-oxazoline) with Different Hydrophobic Blocks: Changes of the Micellar Structures upon Addition of a Strongly Hydrophobic Cancer Drug Macromolecular Chemistry and Physics 217 (2016) 1448-1456.

[19] K.L. Eskow Jaunarajs, D.G. Standaert, T.X. Viegas, M.D. Bentley, Z. Fang, B. Dizman, K. Yoon, R. Weimer, P. Ravenscroft, T.H. Johnston, M.P. Hill, J.M. Brotchie, R.W. Moreadith, Rotigotine polyoxazoline conjugate SER-214 provides robust and sustained antiparkinsonian benefit, Movement disorders : official journal of the Movement Disorder Society, 28 (2013) 1675-1682.

[20] B. Rasolonjatovo, J.P. Gomez, W. Meme, C. Goncalves, C. Huin, V. Bennevault-Celton, T. Le Gall, T. Montier, P. Lehn, H. Cheradame, P. Midoux, P. Guegan, Poly(2-methyl-2oxazoline)-b-poly(tetrahydrofuran)-b-poly(2-methyl-2-oxazoline) amphiphilic triblock copolymers: synthesis, physicochemical characterizations, and hydrosolubilizing properties, Biomacromolecules, 16 (2015) 748-756.

[21] B.B. Aggarwal, K.B. Harikumar, Potential therapeutic effects of curcumin, the antiinflammatory agent, against neurodegenerative, cardiovascular, pulmonary, metabolic, 
autoimmune and neoplastic diseases, The international journal of biochemistry \& cell biology, 41 (2009) 40-59.

[22] P. Anand, A.B. Kunnumakkara, R.A. Newman, B.B. Aggarwal, Bioavailability of curcumin: problems and promises., Mol. Pharmaceutics, 4 (2007) 807-818.

[23] D. Lelli, A. Sahebkar, T.P. Johnston, C. Pedone, Curcumin use in pulmonary diseases: State of the art and future perspectives, Pharmacological research, 115 (2017) 133-148.

[24] J.R. Riordan, J.M. Rommens, B. Kerem, N. Alon, R. Rozmahel, Z. Grzelczak, J. Zielenski, S. Lok, N. Plavsic, J.L. Chou, et al., Identification of the cystic fibrosis gene: cloning and characterization of complementary DNA, Science, 245 (1989) 1066-1073.

[25] C.L. Ward, S. Omura, R.R. Kopito, Degradation of CFTR by the ubiquitin-proteasome pathway, Cell, 83 (1995) 121-127.

[26] A.L. Berger, C.O. Randak, L.S. Ostedgaard, P.H. Karp, D.W. Vermeer, M.J. Welsh, Curcumin stimulates cystic fibrosis transmembrane conductance regulator $\mathrm{Cl}$ - channel activity, J Biol Chem, 280 (2005) 5221-5226.

[27] M.E. Egan, M. Pearson, S.A. Weiner, V. Rajendran, D. Rubin, J. Glockner-Pagel, S. Canny, K. Du, G.L. Lukacs, M.J. Caplan, Curcumin, a major constituent of turmeric, corrects cystic fibrosis defects, Science, 304 (2004) 600-602.

[28] B.R. Grubb, S.E. Gabriel, A. Mengos, M. Gentzsch, S.H. Randell, A.M. Van Heeckeren, M.R. Knowles, M.L. Drumm, J.R. Riordan, R.C. Boucher, SERCA pump inhibitors do not correct biosynthetic arrest of deltaF508 CFTR in cystic fibrosis., Am. J. Respir. Cell Mol. Biol., 34 (2006) 355-363.

[29] E. Bruscia, F. Sangiuolo, P. Sinibaldi, K.K. Goncz, G. Novelli, D.C. Gruenert, Isolation of CF cell lines corrected at DeltaF508-CFTR locus by SFHR-mediated targeting, Gene Ther, 9 (2002) 683-685. 
[30] K. Kunzelmann, E.M. Schwiebert, P.L. Zeitlin, W.L. Kuo, B.A. Stanton, D.C. Gruenert, An immortalized cystic fibrosis tracheal epithelial cell line homozygous for the delta F508 CFTR mutation, Am J Respir Cell Mol Biol, 8 (1993) 522-529.

[31] A.L. Cozens, M.J. Yezzi, K. Kunzelmann, T. Ohrui, L. Chin, K. Eng, W.E. Finkbeiner, J.H. Widdicombe, D.C. Gruenert, CFTR expression and chloride secretion in polarized immortal human bronchial epithelial cells, Am J Respir Cell Mol Biol, 10 (1994) 38-47.

[32] W. Meme, M. Vandecasteele, C. Giaume, L. Venance, Electrical coupling between hippocampal astrocytes in rat brain slices, Neuroscience research, 63 (2009) 236-243.

[33] F. Munkonge, E.W. Alton, C. Andersson, H. Davidson, A. Dragomir, A. Edelman, R. Farley, L. Hjelte, G. McLachlan, M. Stern, G.M. Roomans, Measurement of halide efflux from cultured and primary airway epithelial cells using fluorescence indicators, Journal of cystic fibrosis : official journal of the European Cystic Fibrosis Society, 3 Suppl 2 (2004) 171-176.

[34] G. Pereira, C. Huin, S. Morariu, V. Bennevault-Celton, P. Guégan, Synthesis of Poly(2methyl-2-oxazoline) Star Polymers with a b-Cyclodextrin Core. , Aust. J. Chem., 65 (2012) 1145-1155.

[35] A. Gilbert, M. Jadot, E. Leontieva, S. Wattiaux-De Coninck, R. Wattiaux, Delta F508 CFTR localizes in the endoplasmic reticulum-Golgi intermediate compartment in cystic fibrosis cells, Exp Cell Res, 242 (1998) 144-152.

[36] M.L. Guerra, E.M. Wauson, K. McGlynn, M.H. Cobb, Muscarinic control of MIN6 pancreatic beta cells is enhanced by impaired amino acid signaling, J Biol Chem, 289 (2014) 14370-14379.

[37] N. Kalin, A. Claass, M. Sommer, E. Puchelle, B. Tummler, DeltaF508 CFTR protein expression in tissues from patients with cystic fibrosis, The Journal of clinical investigation, 103 (1999) 1379-1389. 
[38] E. Caci, A. Caputo, A. Hinzpeter, N. Arous, P. Fanen, N. Sonawane, A.S. Verkman, R. Ravazzolo, O. Zegarra-Moran, L.J. Galietta, Evidence for direct CFTR inhibition by CFTR(inh)-172 based on Arg347 mutagenesis, Biochem J, 413 (2008) 135-142.

[39] C. Muanprasat, N.D. Sonawane, D. Salinas, A. Taddei, L.J. Galietta, A.S. Verkman, Discovery of glycine hydrazide pore-occluding CFTR inhibitors: mechanism, structureactivity analysis, and in vivo efficacy, The Journal of general physiology, 124 (2004) 125137.

[40] E.M. Schwiebert, M.E. Egan, T.H. Hwang, S.B. Fulmer, S.S. Allen, G.R. Cutting, W.B. Guggino, CFTR regulates outwardly rectifying chloride channels through an autocrine mechanism involving ATP, Cell, 81 (1995) 1063-1073.

[41] J.J. Wine, W.E. Finkbeiner, C. Haws, M.E. Krouse, S. Moon, J.H. Widdicombe, Y. Xia, CFTR and other Cl- channels in human airway cells, The Japanese journal of physiology, 44 Suppl 2 (1994) S199-205.

[42] J. Zeng, N. Yang, X.M. Li, P.J. Shami, J. Zhan, 4'-O-methylglycosylation of curcumin by Beauveria bassiana, Nat Prod Commun, 5 (2010) 77-80.

[43] F. Zhang, G.Y. Koh, D.P. Jeansonne, J. Hollingsworth, P.S. Russo, G. Vicente, R.W. Stout, Z. Liu, A novel solubility-enhanced curcumin formulation showing stability and maintenance of anticancer activity, J Pharm Sci, 100 (2011) 2778-2789.

[44] S. Mishra, U. Narain, R. Mishra, K. Misra, Design, development and synthesis of mixed bioconjugates of piperic acid-glycine, curcumin-glycine/alanine and curcumin-glycine-piperic acid and their antibacterial and antifungal properties, Bioorg Med Chem, 13 (2005) 14771486.

[45] C.Y. Kim, N. Bordenave, M.G. Ferruzzi, A. Safavy, K.H. Kim, Modification of curcumin with polyethylene glycol enhances the delivery of curcumin in preadipocytes and its antiadipogenic property, J Agric Food Chem, 59 (2011) 1012-1019. 
[46] M.K. Pandey, S. Kumar, R.K. Thimmulappa, V.S. Parmar, S. Biswal, A.C. Watterson, Design, synthesis and evaluation of novel PEGylated curcumin analogs as potent Nrf2 activators in human bronchial epithelial cells, Eur J Pharm Sci, 43 (2011) 16-24.

[47] S.S. Bansal, M. Goel, F. Aqil, M.V. Vadhanam, R.C. Gupta, Advanced drug delivery systems of curcumin for cancer chemoprevention, Cancer Prev Res (Phila), 4 (2011) 11581171.

[48] M.M. Yallapu, M. Jaggi, S.C. Chauhan, Curcumin nanoformulations: a future nanomedicine for cancer, Drug Discov Today, 17 (2011) 71-80.

[49] M.M. Yallapu, M. Jaggi, S.C. Chauhan, Poly(beta-cyclodextrin)/curcumin self-assembly: a novel approach to improve curcumin delivery and its therapeutic efficacy in prostate cancer cells, Macromol Biosci, 10 (2010) 1141-1151.

[50] S. Mourtas, M. Canovi, C. Zona, D. Aurilia, A. Niarakis, B. La Ferla, M. Salmona, F. Nicotra, M. Gobbi, S.G. Antimisiaris, Curcumin-decorated nanoliposomes with very high affinity for amyloid-beta1-42 peptide, Biomaterials, 32 (2011) 1635-1645.

[51] N.K. Narayanan, D. Nargi, C. Randolph, B.A. Narayanan, Liposome encapsulation of curcumin and resveratrol in combination reduces prostate cancer incidence in PTEN knockout mice, Int J Cancer, 125 (2009) 1-8.

[52] D. Wang, M.S. Veena, K. Stevenson, C. Tang, B. Ho, J.D. Suh, V.M. Duarte, K.F. Faull, K. Mehta, E.S. Srivatsan, M.B. Wang, Liposome-encapsulated curcumin suppresses growth of head and neck squamous cell carcinoma in vitro and in xenografts through the inhibition of nuclear factor kappaB by an AKT-independent pathway, Clin Cancer Res, 14 (2008) 62286236.

[53] J. Duan, Y. Zhang, S. Han, Y. Chen, B. Li, M. Liao, W. Chen, X. Deng, J. Zhao, B. Huang, Synthesis and in vitro/in vivo anti-cancer evaluation of curcumin-loaded chitosan/poly(butyl cyanoacrylate) nanoparticles, Int J Pharm, 400 (2010) 211-220. 
661

662

663

664

665

666

667

668

669

670

671

672

673

674

675

676

677

678

679

680

681

682

683

684

685

[54] R. Mulik, K. Mahadik, A. Paradkar, Development of curcuminoids loaded poly(butyl) cyanoacrylate nanoparticles: Physicochemical characterization and stability study, Eur J Pharm Sci, 37 (2009) 395-404.

[55] M.M. Yallapu, B.K. Gupta, M. Jaggi, S.C. Chauhan, Fabrication of curcumin encapsulated PLGA nanoparticles for improved therapeutic effects in metastatic cancer cells, J Colloid Interface Sci, 351 (2010) 19-29.

[56] X. Yang, Z. Li, N. Wang, L. Li, L. Song, T. He, L. Sun, Z. Wang, Q. Wu, N. Luo, C. Yi, C. Gong, Curcumin-encapsulated polymeric micelles suppress the development of colon cancer in vitro and in vivo, Scientific reports, 5 (2015) 10322.

[57] M.S. Cartiera, E.C. Ferreira, C. Caputo, M.E. Egan, M.J. Caplan, W.M. Saltzman, Partial correction of cystic fibrosis defects with PLGA nanoparticles encapsulating curcumin, Mol Pharm, 7 (2010) 86-93.

[58] K. Knop, R. Hoogenboom, D. Fischer, U.S. Schubert, Poly(ethylene glycol) in drug delivery: pros and cons as well as potential alternatives, Angewandte Chemie, 49 (2010) 6288-6308.

[59] T.X. Viegas, M.D. Bentley, J.M. Harris, Z. Fang, K. Yoon, B. Dizman, R. Weimer, A. Mero, G. Pasut, F.M. Veronese, Polyoxazoline: chemistry, properties, and applications in drug delivery, Bioconjugate chemistry, 22 (2011) 976-986.

[60] C. Huin, T. Le Gall, B. Barteau, B. Pitard, T. Montier, P. Lehn, H. Cheradame, P. Guegan, Evidence of DNA transfer across a model membrane by a neutral amphiphilic block copolymer, J Gene Med, 13 (2011) 538-548.

[61] T. Okiyoneda, A. Niibori, K. Harada, T. Kohno, M. Michalak, M. Duszyk, I. Wada, M. Ikawa, T. Shuto, M.A. Suico, H. Kai, Role of calnexin in the ER quality control and productive folding of CFTR; differential effect of calnexin knockout on wild-type and DeltaF508 CFTR, Biochim Biophys Acta, 1783 (2008) 1585-1594. 
[62] S. Kamhi-Nesher, M. Shenkman, S. Tolchinsky, S.V. Fromm, R. Ehrlich, G.Z. Lederkremer, A novel quality control compartment derived from the endoplasmic reticulum, Mol Biol Cell, 12 (2001) 1711-1723.

[63] J. Butler, H.R. Watson, A.G. Lee, H.J. Schuppe, J.M. East, Retrieval from the ER-golgi intermediate compartment is key to the targeting of c-terminally anchored ER-resident proteins, J Cell Biochem, 112 (2011) 3543-3548.

[64] N. Melis, M. Tauc, M. Cougnon, S. Bendahhou, S. Giuliano, I. Rubera, C. Duranton, Revisiting CFTR inhibition: a comparative study of CFTRinh -172 and GlyH-101 inhibitors, British journal of pharmacology, 171 (2014) 3716-3727.

[65] J.G. Bilmen, S.Z. Khan, M.H. Javed, F. Michelangeli, Inhibition of the SERCA Ca2+ pumps by curcumin. Curcumin putatively stabilizes the interaction between the nucleotidebinding and phosphorylation domains in the absence of ATP, Eur J Biochem, 268 (2001) 6318-6327.

[66] M.J. Logan-Smith, P.J. Lockyer, J.M. East, A.G. Lee, Curcumin, a molecule that inhibits the $\mathrm{Ca} 2+-\mathrm{ATPase}$ of sarcoplasmic reticulum but increases the rate of accumulation of $\mathrm{Ca} 2+, \mathrm{J}$ Biol Chem, 276 (2001) 46905-46911.

[67] C. Norez, S. Noel, M. Wilke, M. Bijvelds, H. Jorna, P. Melin, H. DeJonge, F. Becq, Rescue of functional delF508-CFTR channels in cystic fibrosis epithelial cells by the alphaglucosidase inhibitor miglustat, FEBS Lett, 580 (2006) 2081-2086.

[68] N. Davezac, D. Tondelier, J. Lipecka, P. Fanen, F. Demaugre, J. Debski, M. Dadlez, A. Schrattenholz, M.A. Cahill, A. Edelman, Global proteomic approach unmasks involvement of keratins 8 and 18 in the delivery of cystic fibrosis transmembrane conductance regulator (CFTR)/deltaF508-CFTR to the plasma membrane, Proteomics, 4 (2004) 3833-3844.

[69] A. Edelman, Cytoskeleton and CFTR, The international journal of biochemistry \& cell biology, 52 (2014) 68-72. 
711 [70] J. Lipecka, C. Norez, N. Bensalem, M. Baudouin-Legros, G. Planelles, F. Becq, A. 712 Edelman, N. Davezac, Rescue of DeltaF508-CFTR (cystic fibrosis transmembrane 713 conductance regulator) by curcumin: involvement of the keratin 18 network, J Pharmacol Exp 714 Ther, 317 (2006) 500-505.

715 [71] J.B. Baell, Feeling Nature's PAINS: Natural Products, Natural Product Drugs, and Pan 716 Assay Interference Compounds (PAINS), Journal of natural products, 79 (2016) 616-628. 
A<smiles>CC(=O)N(CCCCC(C)(C)OCCCCC(C)N(CCC(C)(C)O)C(C)=O)C(C)=O</smiles>

B

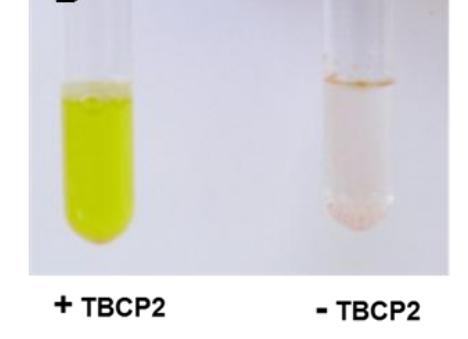

D

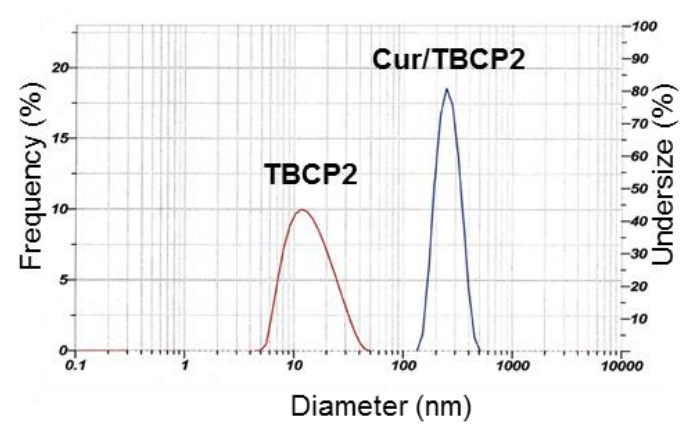

Figure 1: (A) Chemical structure of the amphiphilic triblock copolymer $\mathrm{MeOx}_{6}-\mathrm{THF}_{19}$ $\mathrm{MeOx}_{6}$ (TBCP2). (B) Cur solubilisation in a TBCP2 aqueous solution. Two mg Cur was added to $5 \mathrm{ml}$ of a $0.2 \%$ TBCP2 solution in water (+TBCP2) or in $5 \mathrm{ml}$ water (-TBCP2). (C) $\mathrm{H}^{1}$ NMR spectrum of TBCP2. (D) Size of TBCP2 micelles and Cur/TBCP2 formulation.

729

730

731

732 


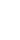




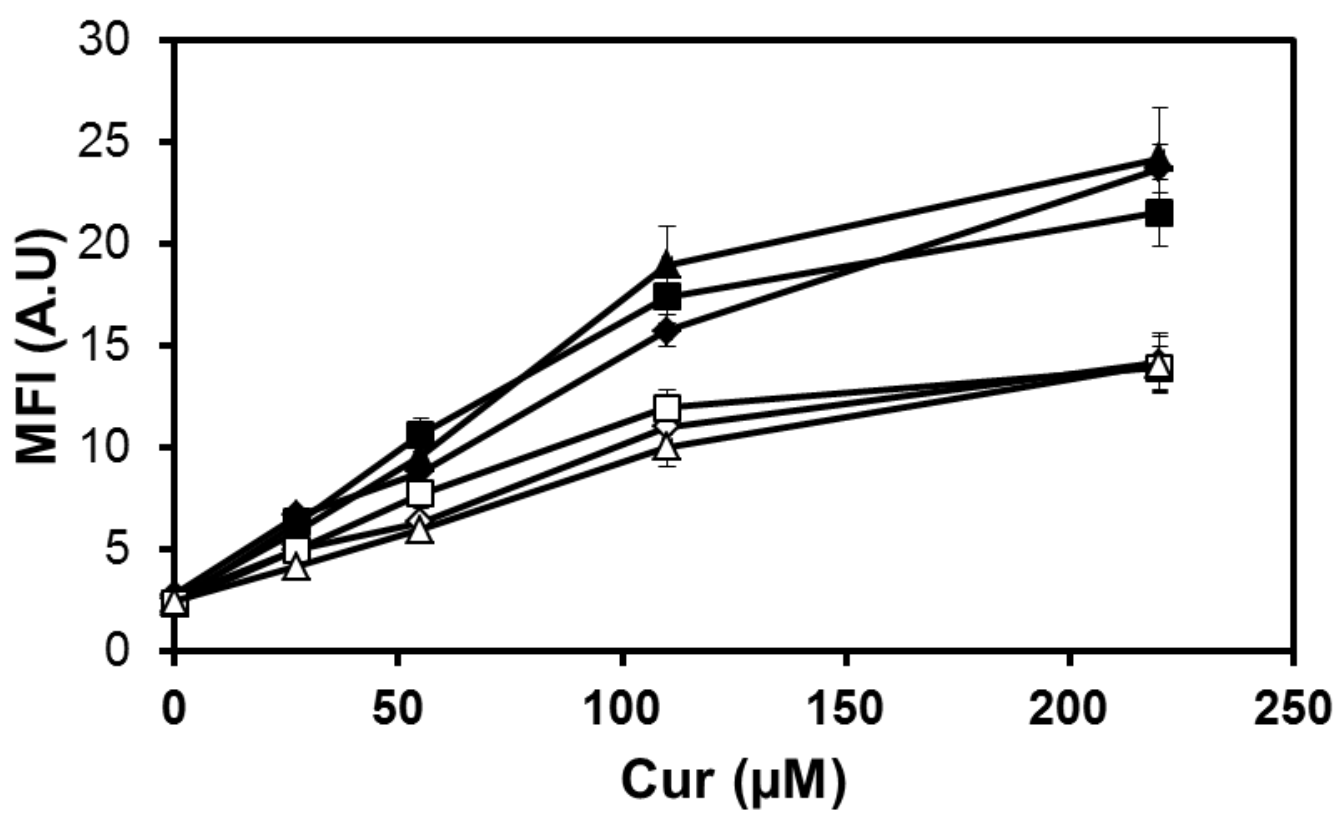

770 Figure 3: Uptake of Cur. $(\diamond, \diamond)$ ECFTE29o-, $(\boldsymbol{\square}, \square)$ 16HBE14o- and $(\boldsymbol{\Delta}, \Delta)$ CFBE41o771 cells were incubated for $2 \mathrm{~h}$ at $37^{\circ} \mathrm{C}$ in the presence of various dilutions of the Cur/TBCP2 772 formulation. The mean fluorescence intensity (MFI) of the cells was measured by flow 773 cytometry ( $\lambda$ ex: $488 \mathrm{~nm}$; $\lambda \mathrm{em}$ : $530 \pm 30 \mathrm{~nm}$ ) before (black symbols) and after (white symbols) 774 treatment with trypan blue. The fluorescence intensity is expressed as MFI value of 10,000 775 cells. 


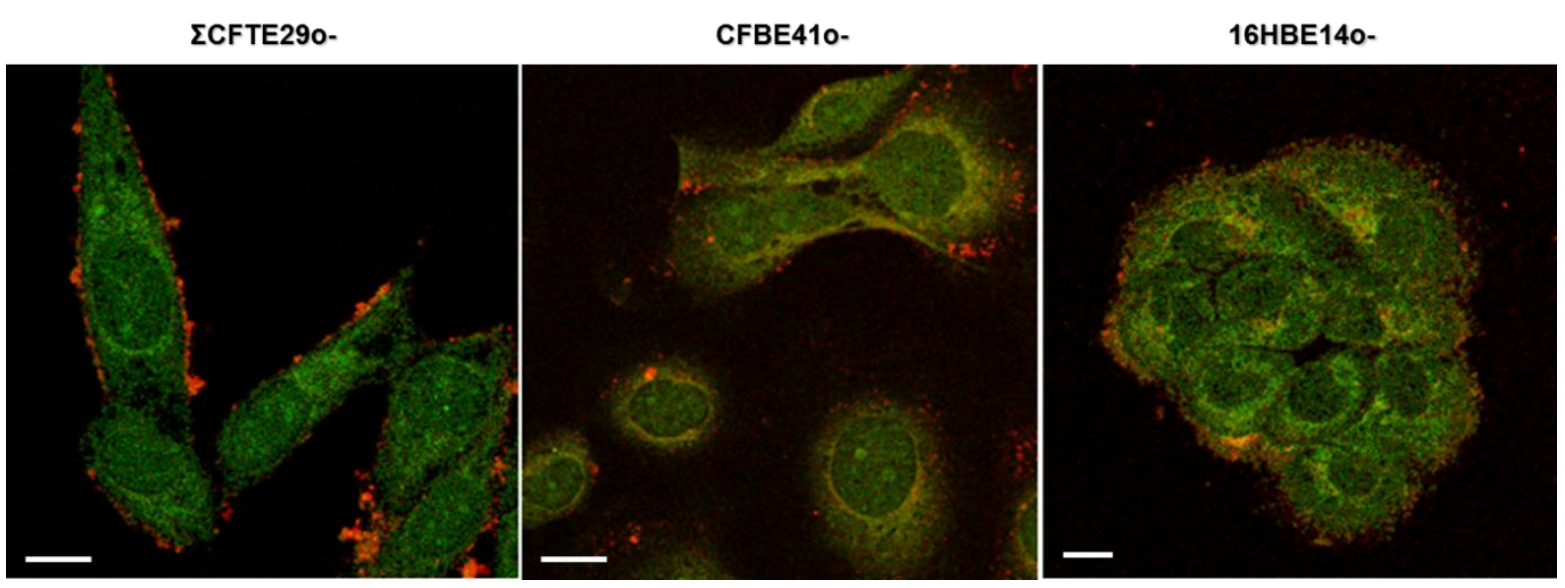

Figure 4: Curcumin and copolymer cellular distribution. $\Sigma$ CFTE29o-, 16HBE140- and 786 CFBE41o- cells $\left(1.4 \times 10^{4}\right)$ were seeded on glass coverslips in $2 \mathrm{~cm}^{2}$ well of a 4-well plastic 787 culture plate. Two days after, the cells were incubated at $37^{\circ} \mathrm{C}$ in the presence of $40 \mu \mathrm{M}$ 788 curcumin solubilised with Rho-TBCP. Upon 4h incubation, cells were washed with PBS 789 coverslips were mounted in Vectashield and analysed by confocal laser scanning microscopy. 790 The fluorescence of curcumin and rhodamine were measured at $520 \mathrm{~nm}$ upon excitation at 791 $488 \mathrm{~nm}$ and $560 \mathrm{~nm}$ upon excitation at $543 \mathrm{~nm}$, respectively. Scale bar: $20 \mu \mathrm{m}$. 

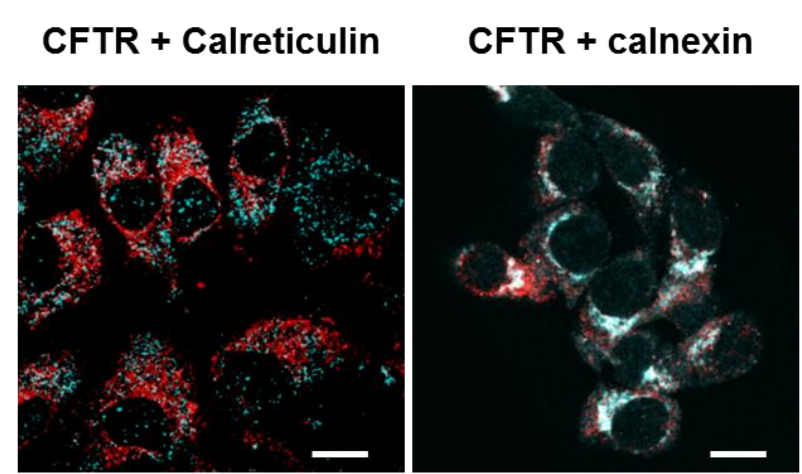
CFTR + ergic -53

¿CFTE290-

CFBE410-
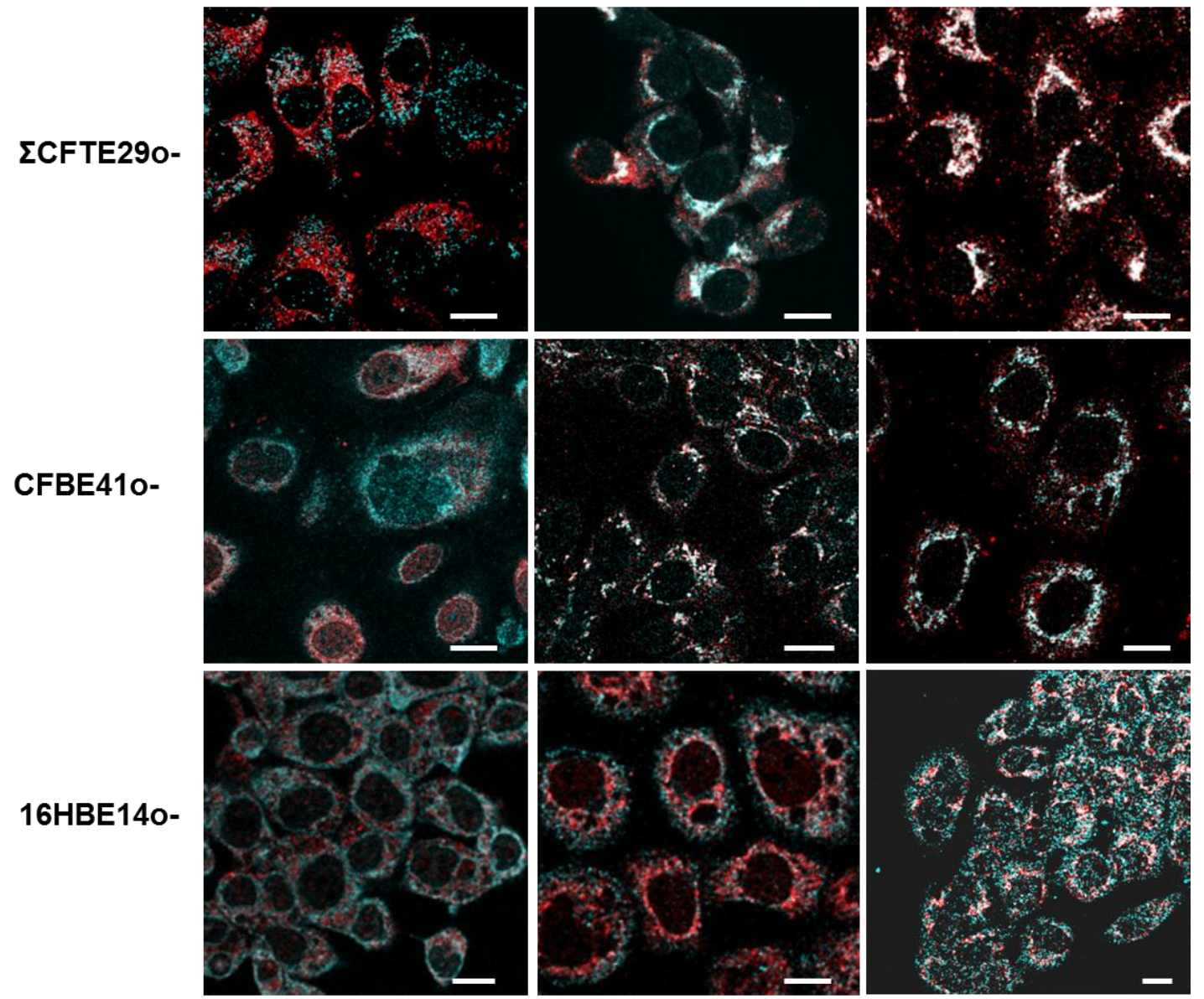

16HBE140-

Figure 5: Confocal microscopy images of CFTR intracellular location. LCFTE29o-, 16HBE14o- and CFBE41o- cells were labelled with mouse anti-hCFTR antibodies and either with anti-calreticulin anti-calnexin or anti-ERGIC-53 antibodies. Anti-hCFTR antibodies were revealed with Cy5 sheep anti-mouse antibodies (blue) and the other antibodies with Alexa Fluor 568 secondary antibodies (red). Scale bar: $20 \mu \mathrm{m}$. 

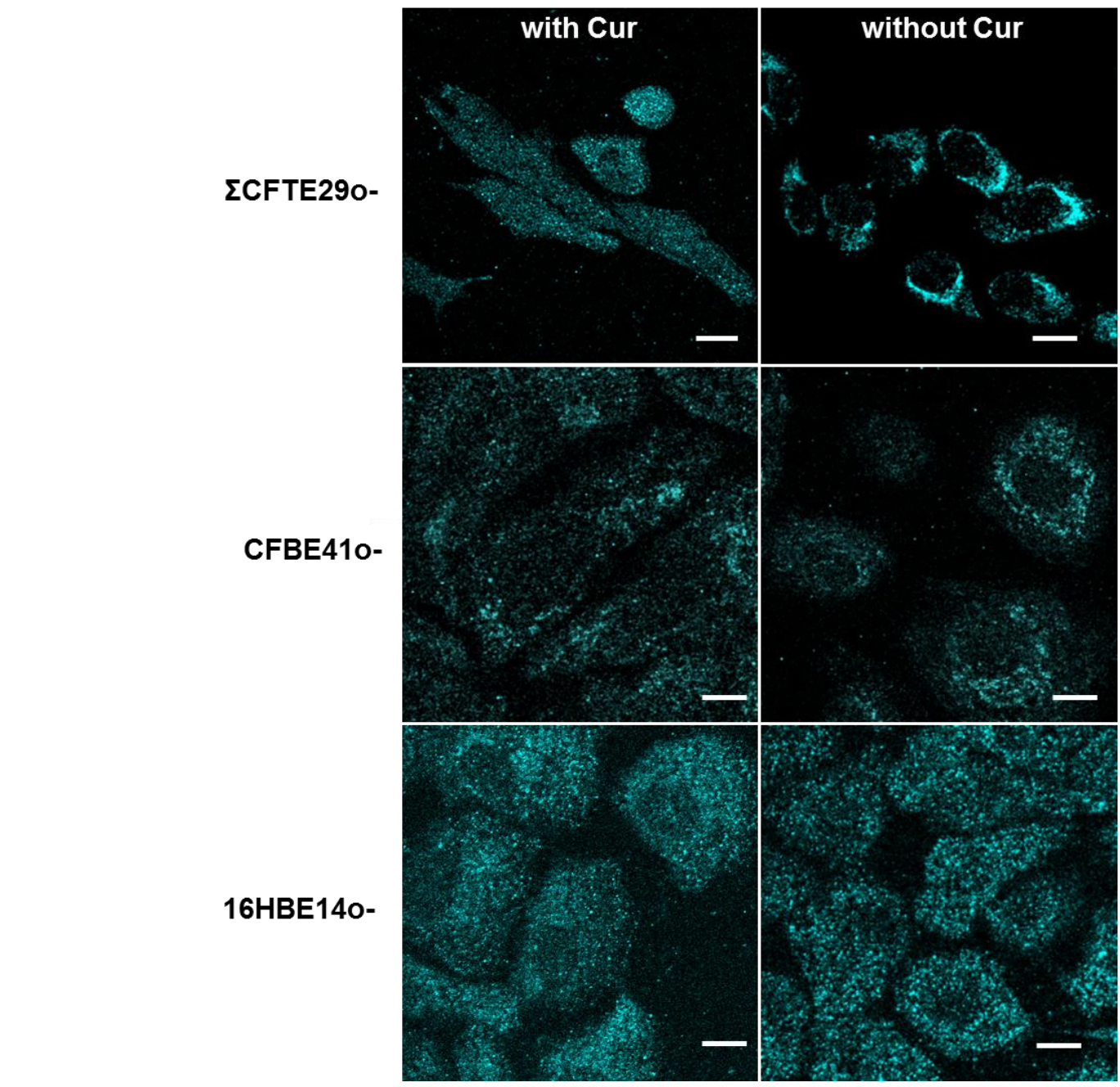

823

824

825

826

827

828

829

830

831

832

833

834

835

\section{1}

Figure 6: Effect of Cur/TBCP2 treatment on the F508del-CFTR location. $\Sigma$ CFTE29o-, CFBE41o- and 16HBE14o- cells were cultured for $16 \mathrm{~h}$ in the absence (without Cur) or the presence (with Cur) of $220 \mu \mathrm{M}$ Cur/TBCP2. The cells were stained with mouse anti-hCFTR antibody followed by Cy5-sheep anti-mouse antibodies. The fluorescence of the cells was analysed by confocal microscopy at $660 \mathrm{~nm}$ upon excitation at $633 \mathrm{~nm}$ (Cy5). Scale bar: 20 $\mu \mathrm{m}$. 

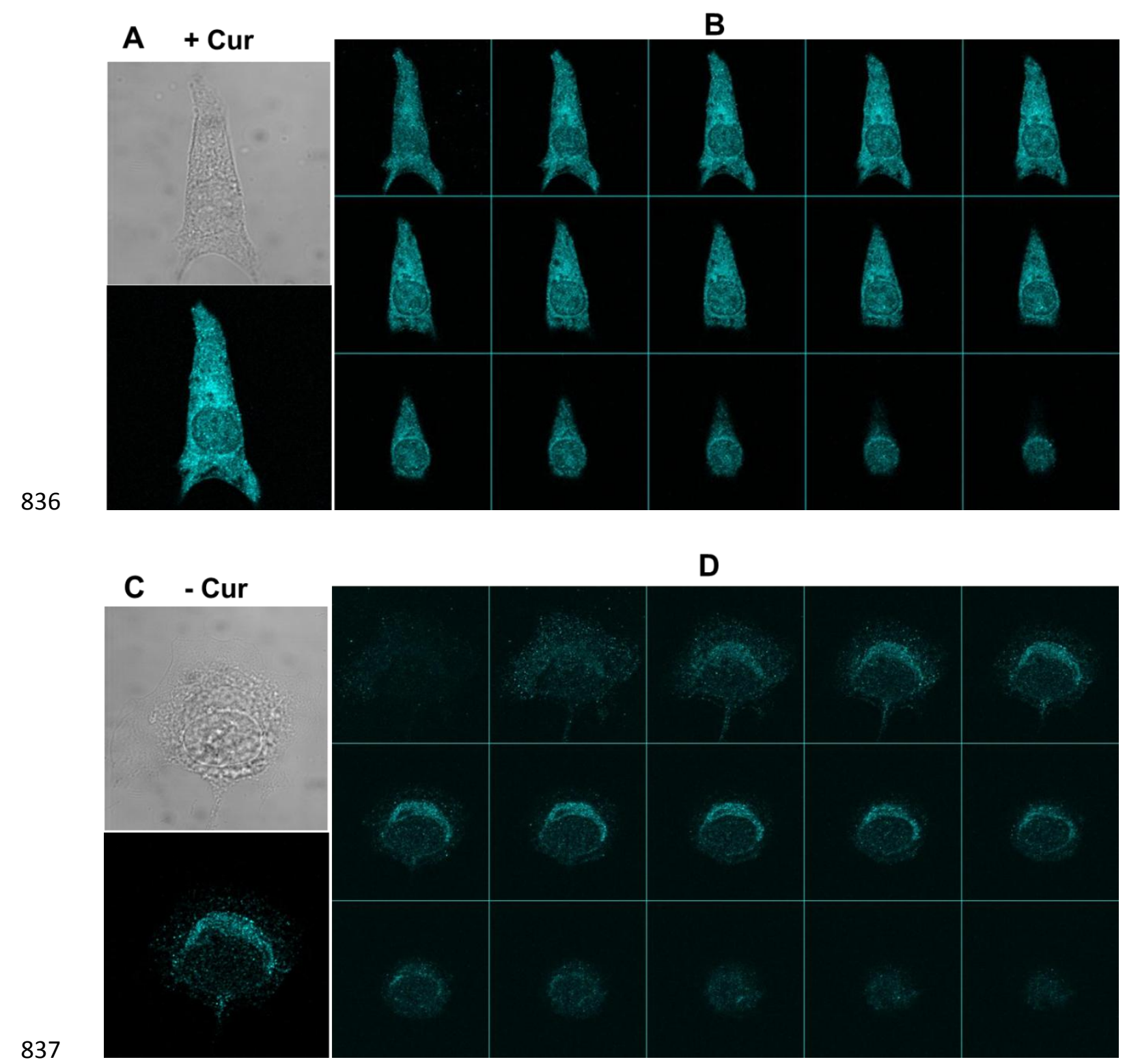

841 Figure 7: Images reconstitution of several z steps $(\mathbf{A}, \mathbf{C})$ and z-step gallery $(\mathbf{B}, \mathbf{D})$ after $(\mathbf{A}, \mathbf{B})$ 842 and before (C, D) Cur/TBCP2 treatment of $\Sigma$ CFTE29o- cells. 


\section{A}

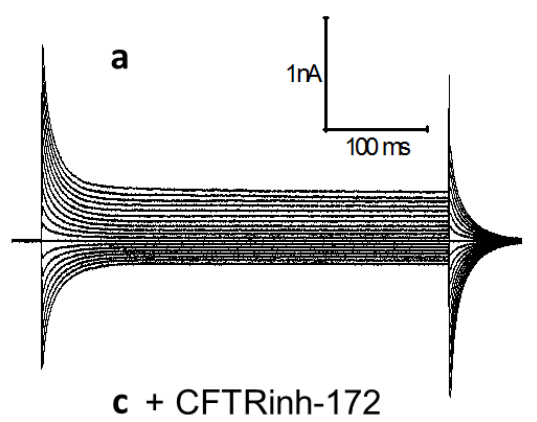

849

850

851

852

853

854

855

856

857

858

859

860

861

862

863

864

865

866

867

868

869

870

871

872

873

874

875

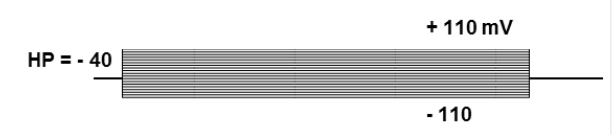

B

25

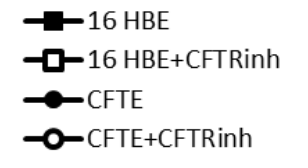

b

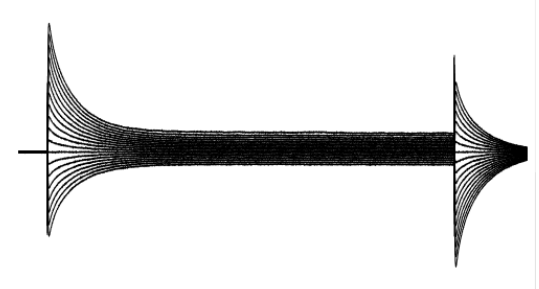

d + CFTRinh-172
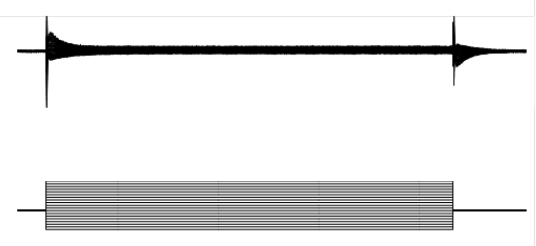

$\mathrm{I}(\mathrm{pA} / \mathrm{pF})$

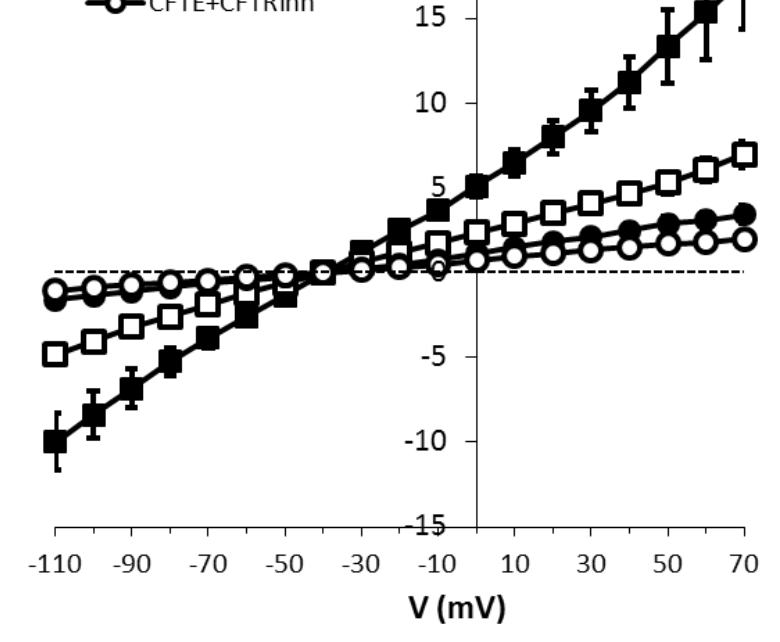

Figure 8: Patch-clamp characterization of CFTR current in normal and CF epithelial cells. (A) Representative whole-cell $\mathrm{Cl}^{-}$current recordings in (a) 16HBE14o- and (b) $\Sigma$ CFTE29o- cultured cells under control conditions or (c and d) after addition of the selective CFTR-inhibitor CFTRinh-172 $(10 \mu \mathrm{M})$ for $10 \mathrm{~min}$ into the bath solution. (B) Plots of averaged steady-state current-voltage relationships (I/V curves) of $\mathrm{Cl}^{-}$currents in the absence (black squares: $16 \mathrm{HBE} 140-$ cells, $\mathrm{n}=5$; black circles: $\sum$ CFTE29o- cells, $\mathrm{n}=9$ ) or after addition of 10 $\mu \mathrm{M}$ CFTRinh-172 for 10 min (white symbols). All results were expressed as mean $\pm \mathrm{SEM}$. 
Figure 9: Patch-clamp measurements of Cur/TBCP2-induced activation of CFTRinh172 sensitive current in $\Sigma$ CFTE29o- cells. (A) Representative whole cell CFTR current traces recorded after cell culture (a) in basal conditions or after $16 \mathrm{~h}$ treatment with (b) Cur/TBCP2 $(120 \mu \mathrm{M})$ or (c) after addition of the selective CFTR-inhibitor CFTRinh-172 (10 $\mu \mathrm{M}$ ) for $10 \mathrm{~min}$ into the bath solution in cells treated with Cur/TBCP2. (B) Plots of averaged steady-state current-voltage relationships (I/V curves) of CFTRinh-172 sensitive currents. I/V curves on cells before treatment (black squares, $n=8$ ), and $16 \mathrm{~h}$ treatment with Cur/TBCP2 (black triangles, $n=19$ ). Steady-state current amplitude was measured at the end of the pulse and normalized to the cell capacitance. All results were expressed as mean \pm SEM. Statistical significance was assessed using Mann-Whitney non-parametric test, and the significance level was established at $\mathrm{p}<0.05$ between CFTRinh-172 sensitive currents measured with Cur/TBCP2. 

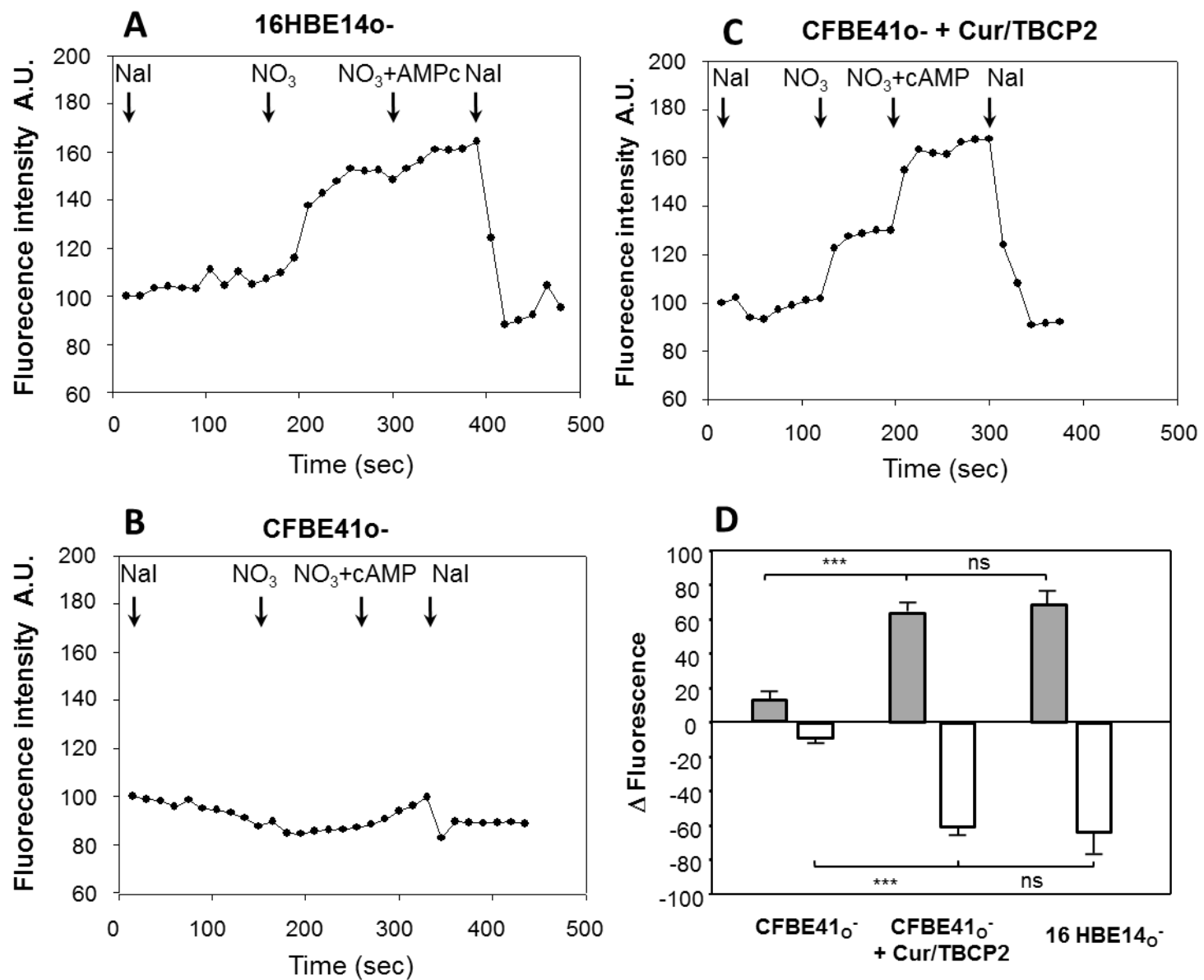

Figure 10: Cur/TBCP2 treatment influence on the CFTR-mediated anion transport on different epithelial cell monolayers measured by MQAE fluorescence. CFBE410- and 16HBE140- cells loaded with MQAE were sequentially perfused with $\mathrm{I}^{-}, \mathrm{NO}_{3}{ }^{-}, \mathrm{NO}_{3}{ }^{-}$with cAMP and again with I' buffer solutions. Representative MQAE fluorescence intensity was plotted as a function of time in (A) 16HBE14o-, (B) untreated CFBE41o- cells or (C) treated CFBE41o- cells for $16 \mathrm{~h}$ with Cur/TBCP2 (165 $\mu \mathrm{M})$. (D) Histograms of fluorescence amplitude variation ( $\Delta$ fluorescence) in cell monolayer without or with Cur/TBCP2 treatment, in the presence of $\mathrm{NO}_{3}{ }^{-}$and $\mathrm{NO}_{3}{ }^{-}+\mathrm{cAMP}$ (grey filled histograms) or $\mathrm{NaI}^{-}$(white histograms) expressed as the difference between the maximal fluorescence intensity measured at steady state before and after the change of the respective solutions. Data are means \pm SEM. Statistical significance was assessed using a Student's $t$-test, and the significance level was established at $\mathrm{p}<0.05(*: \mathrm{p}<0.05 ; * *: \mathrm{p}<0.01 ; * * *: \mathrm{p}<0.00 .1)$. ns: non-significant. 
939

940

941

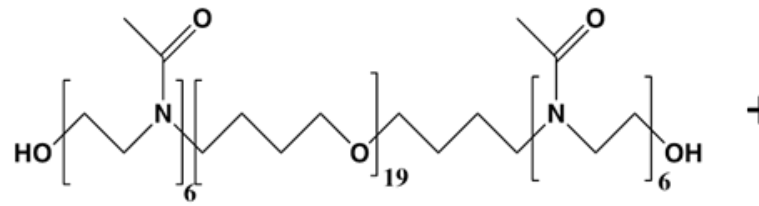

TBCP2

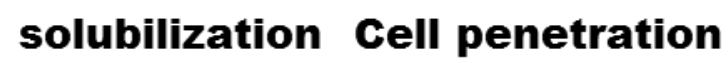<smiles>COc1cc(/C=C/C(=O)/C=C(O)/C=C/c2ccc(O)c(OC)c2)ccc1O</smiles>

Cur

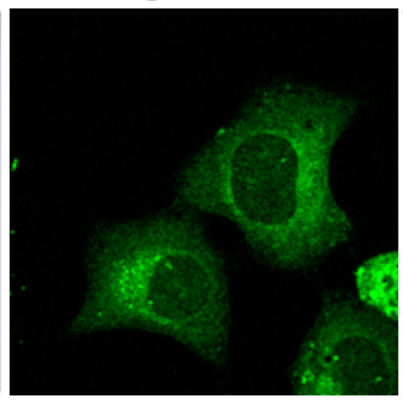

CFTR relocalisation
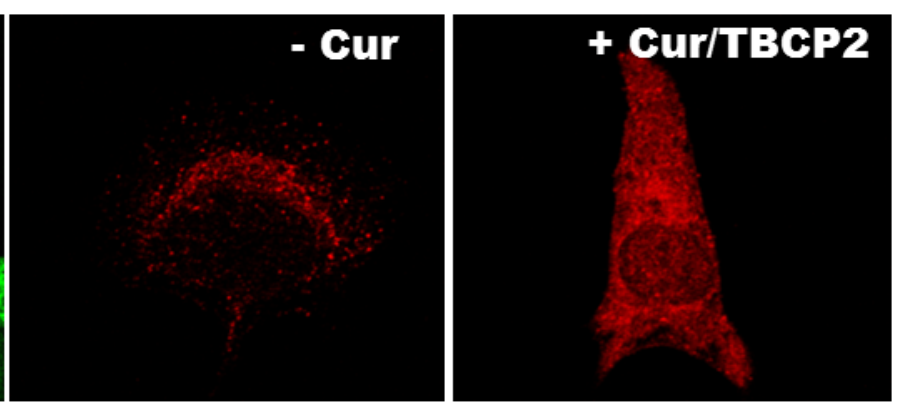

Chloride transport restoration



942 